\title{
13. PROCESSES OF VOLCANICLASTIC SEDIMENTATION DURING THE EARLY GROWTH STAGES OF GRAN CANARIA BASED ON SEDIMENTS FROM SITE $953^{1}$
}

\author{
Steven Carey, ${ }^{2}$ Tony Maria, ${ }^{2}$ and Winton Cornell ${ }^{3}$
}

\begin{abstract}
Site 953 recovered a 14.8-Ma record of volcaniclastic sedimentation adjacent to Gran Canaria Island of the Canary Island archipelago. Changes in the lithology, age, and volume of clastic material reflect the evolution of Gran Canaria from a submarine stage to a mature subaerial edifice. Before the initiation of major felsic explosive volcanism on Gran Canaria at 14.0 Ma, there was a period during which numerous mafic volcaniclastic turbidites were generated from the emergent island (Unit V, Site 953). The deposits consist of sand- to silt-sized mixtures of altered sideromelane, tachylite, small clasts of microcrystalline basalt, and crystals of clinopyroxene, feldspar, and Fe-Ti oxides. Biogenic components, such as foraminifer fragments, make up as much as $30 \%$.

Computer-assisted fractal analysis of sideromelane grain morphologies shows a decrease in morphological complexity with increasing age through Unit V. This change, along with a decrease in the modal abundance of tachylite with increasing age, is interpreted to represent an increasing role of deeper, submarine volcanism as the source of clastic particles early in the island's development. The strongly mixed lithologies of the turbidites and the occurrence of common, rounded microcrystalline basalt fragments suggest that many of the layers were formed by the slumping of volcaniclastic material that had accumulated in shallow water from erosion of subaerial products, the entrance of lava flows into the sea, and shallow submarine eruptions. A median frequency of one flow event every $2000 \mathrm{yr}$ has been determined from the thickness and accumulation rate of interbedded pelagic sediment in Unit V.
\end{abstract}

\section{INTRODUCTION}

The growth of oceanic islands is an important component in the exchange of material from the Earth's mantle to the surface. Their history and evolution are critical to understanding the rates at which magma is supplied to the crust and at which marine and subaerial processes convert primary volcanic products into clastic sediments. Deciphering the growth processes of oceanic volcanoes based on the subaerial sequences is often difficult because of the incomplete preservation of erupted products and the inability to access the earliest deposits. During Ocean Drilling Program (ODP) Leg 157, four sites $(953,954,955$, and 956) were drilled into the volcaniclastic apron of Gran Canaria island in an attempt to recover the sedimentary record of submarine growth and subaerial emergence and activity. The island was selected because of its well-characterized subaerial volcanic history and the great compositional diversity of erupted products (Schmincke, 1982, 1993). One of the major objectives of Leg 157 was to examine the various evolutionary stages of Gran Canaria in detail from its inception on the seafloor to its present subaerial configuration (Schmincke et al., 1994).

Much is known about the volumes and compositions of erupted products from the subaerial volcanic activity of Gran Canaria (Schmincke, 1993). Principal features include two major phases of felsic volcanism in the middle Miocene and a third, less voluminous, Pliocene episode. The most voluminous phase occurred between 14.0 and 13.4 Ma and involved eruption of trachyte, peralkaline rhyolites, and alkali basalts (Mogán Formation). Much less is known about the pre-Mogán history of the island, when the rates of volcanic activity are inferred to be high and much of the shield-building stage was taking place. Recovery of volcaniclastic sediments of this age surround-

${ }^{1}$ Weaver, P.P.E., Schmincke, H.-U., Firth, J.V., and Duffield, W. (Eds.), 1998. Proc. $O D P$, Sci. Results, 157: College Station, TX (Ocean Drilling Program).

${ }^{2}$ Graduate School of Oceanography, University of Rhode Island, Narragansett, RI 02882, U.S.A. scarey@gsosun1.gso.uri.edu

${ }^{3}$ Department of Geosciences, University of Tulsa, Tulsa, OK 74104, U.S.A. ing Gran Canaria provides an excellent opportunity to investigate this stage of the island's history and to develop a complete reconstruction of the island's evolution.

In this paper we present a study of the volcaniclastic deposits comprising Unit V of Site 953. This unit has been correlated to the pre-Mogán stage of volcanism in the Canary Islands based on its stratigraphic position and composition (Shipboard Scientific Party, 1995). The work focuses on the lithology and sedimentology of the deposits with the objective of constructing a model for the origin and emplacement of volcaniclastic sediment on the island flanks.

\section{METHODS}

As part of this project, Sections 157-953C-71R-1 through 74R-6 were re-examined at the ODP core repository in Bremen, Germany, to check for boundaries between units emplaced by sediment gravity flows and those deposited by pelagic or hemipelagic sedimentation. The criteria for the recognition of gravity flow deposits included existence of a sharp base, grading of particle size, presence of sedimentary structures, such as laminations or cross-bedding, and the occurrence of bioturbated tops. As a result of this examination, the identification of depositional layers was changed slightly from those recorded in the shipboard visual core descriptions.

Indurated samples of volcaniclastic gravity flow deposits and pelagic sediment were cut from Cores 157-953C-71R through 75R and impregnated with epoxy for preparation of polished thin sections. Modal analysis of the layers was carried out on a Zeiss Axioskop petrographic microscope with an electromechanical stage by counting 1500 grains per sample. Approximation of maximum grain size was carried out by determining the size of the 10 largest volcanic particles in each thin section, using a video imaging system interfaced with a petrographic microscope.

Bulk samples of representative layers were analyzed for major and trace elements using X-ray fluorescence (XRF) at the Department of Geology, University of Rhode Island. Powders for XRF anal-

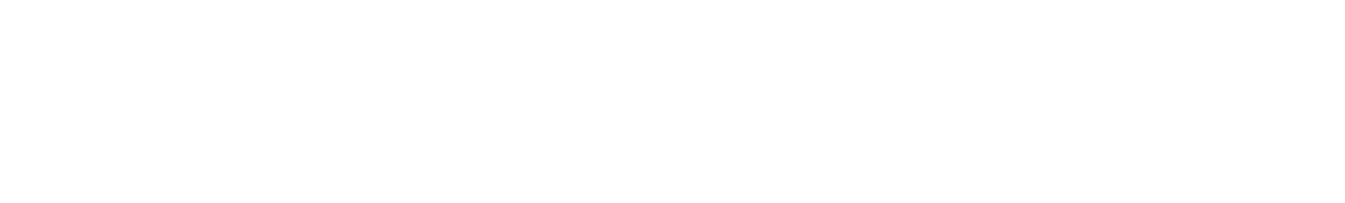


ysis were prepared by crushing cleaned and dried sediment samples to $<2 \mathrm{~mm}$ in diameter in a steel mortar and then grinding and homogenizing the sample in an agate mortar. Analytical methods were carried out according to Danforth (1986) and Hamidzada (1988). U.S. Geological Survey rock standards AGV-1 and W-2 were analyzed in duplicate as a monitor for precision and accuracy. In addition, thin sections were analyzed using energy dispersive spectroscopy (EDS) and image analysis software packages on the microprobe that allow for the rapid geochemical characterization of a large number of grains in a single scanned field.

Morphologies of particles from flow deposits were quantified using fractal dimension analysis of boundary outlines (e.g., Orford and Whalley, 1983). Images of particles were obtained from a digital CCD black and white video camera attached to a petrographic microscope and from scanning electron microscopy (SEM) photography of thin sections. NIH Image 1.58 and Image Fractal software were used to process images and to carry out fractal dimension calculations.

\section{BACKGROUND}

Site 953, located $70 \mathrm{~km}$ northeast of the island of Gran Canaria at a water depth of $3577.8 \mathrm{~m}$ (Fig. 1), recovered a 1053-m-thick succession containing an excellent record of volcaniclastic sedimentation from middle Miocene to the present. Other sites to the west (Site 954) and south (Sites 955 and 956) are complicated by extensive sequences of slump sediments and hiatuses (Schmincke, Weaver, Firth, et al., 1995). The lithostratigraphy of Site 953 was divided into seven major units (Fig. 2) based on the abundance and lithology of volcaniclastic material (Shipboard Scientific Party, 1995). Units I through IV correlate very well in terms of timing and lithology with the major episodes of Gran Canaria felsic volcanism, as inferred from the subaerial geology, and they demonstrate the fundamental role of the island in supplying subaerially generated volcaniclastic sediment to adjacent marine basins. Unit $\mathrm{V}$ represents a marked change in the nature of the source material and is characterized by dominantly mafic compositions with a very high flux of coarse- to medium-grained material to the deep marine environment by sediment gravity flows. It is $49 \mathrm{~m}$ thick with a total recovery of $72.5 \%$. A preliminary interpretation is that this unit represents the early (middle Miocene) history of the island when it was establishing itself as a subaerial edifice.

A distinctive feature of this unit is the very high frequency of sediment gravity flow deposits and their relatively uniform thickness $(\sim 6-8 \mathrm{~cm})$. At least 200 individual deposits were recognized during the initial description of the cores.

\section{VOLCANICLASTIC GRAVITY FLOW DEPOSITS}

We have recognized 265 gravity flow deposits within Unit V, interbedded with nannofossil-mixed sedimentary rock, nannofossil claystone, and claystone. Thicknesses vary from 1 to $58 \mathrm{~cm}$, with a distinct peak in the thickness distribution at $6-8 \mathrm{~cm}$ (Fig. 3). The maximum thickness and number of deposits may be underestimated as a result of incomplete core recovery. Of the total recovered sediment in Unit $\mathrm{V}, 76 \%$ constitutes gravity flow deposits, with the remainder consisting of pelagic or hemipelagic deposits. The percentage of flow deposits is not, however, constant throughout Unit V. We have calculated the percentage of flow deposits on a per section basis and have plotted the results as a function of sub-bottom depth (Fig. 4). There is an overall increase in the percentage of flow deposits with increasing depth, or age, in Unit V. One point at 882 meters below seafloor (mbsf) falls significantly off the trend and is attributed to coring disturbance in the section (Fig. 4).

The time interval between gravity flow events was determined using a modified age/depth model based on biostratigraphic datums

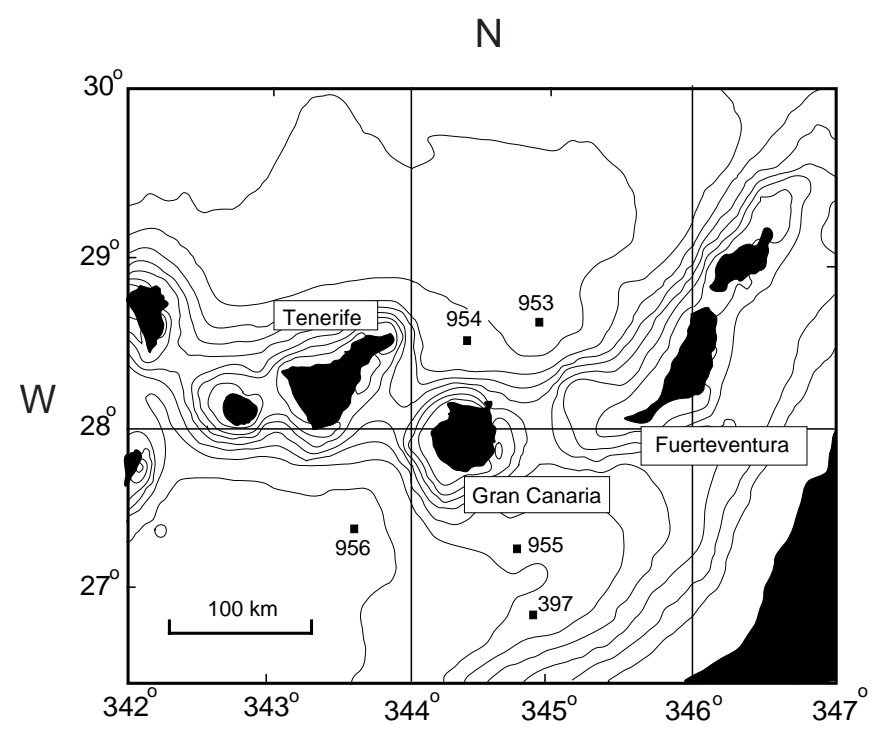

Figure 1. Map showing the locations of Site 953 and other Volcanic Island Clastic Apron Project sites (Leg 157) in relation to the islands of Tenerife, Gran Canaria, and Fuerteventura. Also shown is the location of DSDP Site 397.

(C. Brunner, pers. comm., 1996). We took the age datums in the vicinity of Unit $\mathrm{V}$ and derived a linear regression for the depth interval 834 to $874 \mathrm{mbsf}$. This regression yields a sedimentation rate of $54 \mathrm{~m} /$ m.y. (Fig. 5). If the percentage of flow deposits $(\sim 75 \%)$ is removed from this rate, it indicates a pelagic deposition rate of $14 \mathrm{~m} / \mathrm{m}$.y. It is possible to calculate the inferred time interval between flow deposits by dividing the thickness of interbedded pelagic sediment by the pelagic sedimentation rate. The time between events varies from $<1000$ yr to $\sim 15,000 \mathrm{yr}$ (Fig. 6A). The median time is close to $2000 \mathrm{yr}$ (Fig. 6B).

Median thicknesses of flow deposits were calculated on a per section basis. There are significant variations in the median thickness through Unit V (Fig. 7). Three pulses of thicker flow deposits are present at 864,869 , and 878 mbsf.

Sediment gravity flow deposits in Unit V exhibit a wide variety of sedimentary structures. The most common type of deposit has a sharp base with cross-bedded or parallel laminated silty sand grading upward into massive silt (Fig. 8; Pl. 1). These units are defined by an upper, bioturbated top that grades into fine-grained biogenic sediment and are usually $5-15 \mathrm{~cm}$ thick (Fig. 8). Using the deep-water facies classification of Pickering et al. (1989), we assign such deposits to the sand-mud couplet class (facies C2.2, C2.3). These are interpreted as the deposits of moderate to dilute turbidity currents. Less common in abundance are thicker $(10-30 \mathrm{~cm})$ deposits with sharp bases, extensive cross-bedding, parallel lamination, and convoluted bedding (Fig. 8). These units are usually coarser grained than the first type, show less bioturbation in their upper levels, and are lighter in color. We assign these to the B2.1 and B2.2 facies (organized) in the sand class of Pickering et al. (1989). The parallel laminated facies (B2.1) are derived from high-concentration turbidity currents by the freezing of the thin traction carpet layers at flow bases. In contrast, the cross-bedded facies (B2.2) are inferred to be deposited by bedload transport beneath dilute turbidity currents. In addition, there are rare examples of normally graded coarse sand to silt beds with sharp bases and tops that are assigned to the $\mathrm{C} 2.1$ facies in the sand class (Fig. 8). These units represent deposition from moderate to high concentration turbidity currents that typically contain only the $\mathrm{T}_{\mathrm{a}}$ subdivision of the Bouma sequence. 


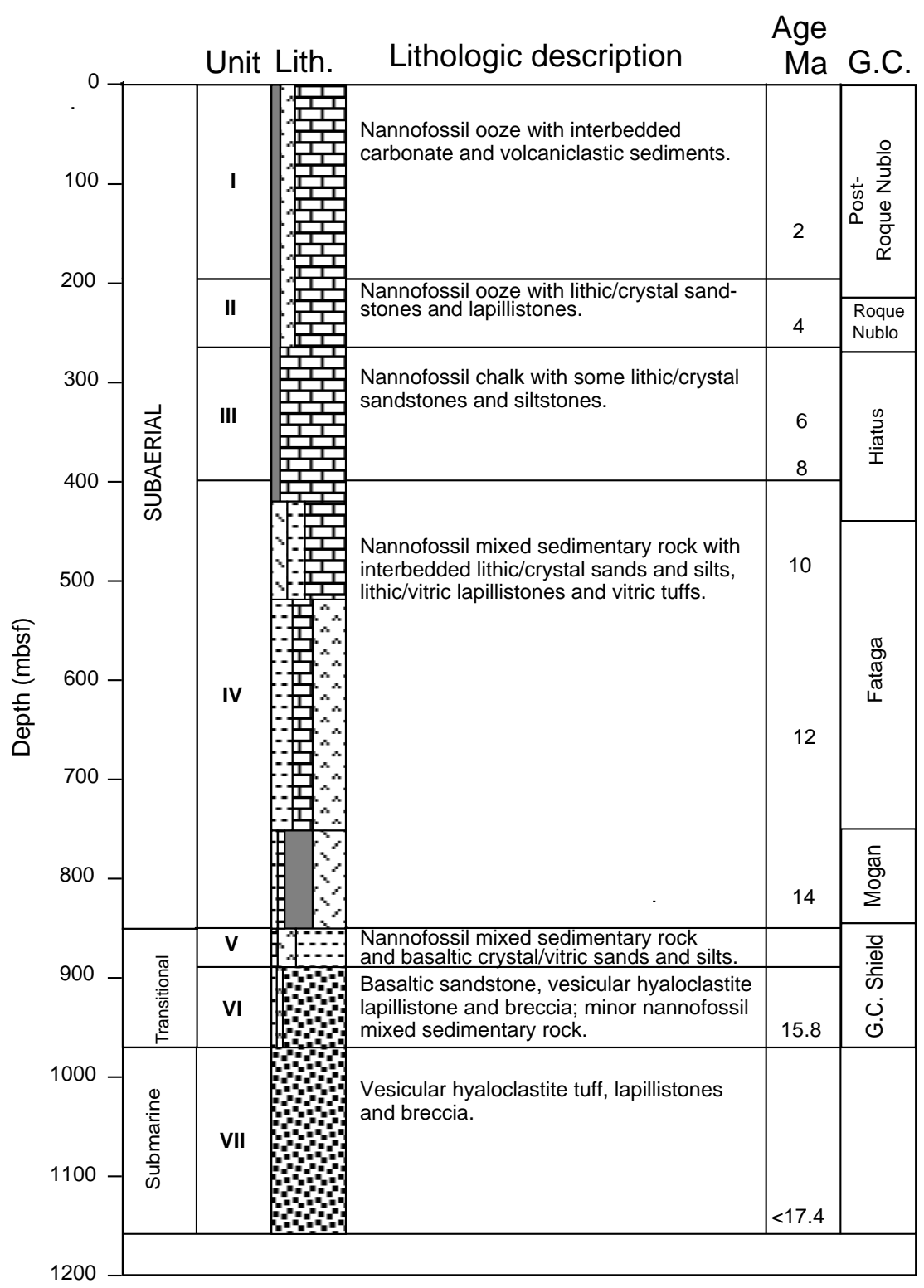

G.C. = correlation to subaerial lithostratigraphy of Gran Canaria (after Schmincke, 1993).
Figure 2. Lithostratigraphic summary of Site 953 showing the seven major units defined by shipboard analysis.

\section{PETROGRAPHY OF SEDIMENT GRAVITY FLOW DEPOSITS}

\section{Texture and Nomenclature}

The great majority of the volcaniclastic deposits of Unit $\mathrm{V}$ are indurated, making grain-size determination by conventional methods difficult. In order to characterize the grain size of the deposits, we measured the 10 largest grains in thin section with an image analysis system. The average size ranges from coarse sand to silt (Table 1). Although many deposits appear to be relatively well sorted, a ubiquitous feature is the presence of a fine-grained matrix (see below).

We adopted the nomenclature of Fisher and Schmincke (1984) for classifying deposits. Volcaniclastic refers to any volcanic particle, regardless of its origin. Indurated deposits consisting predominately of primary volcanic particles (pyroclastic and hydroclastic) are referred to as tuffs $(0.063-2 \mathrm{~mm})$ or lapillistones $(>2 \mathrm{~mm})$. Epiclastic is a term used to refer to clasts formed by the erosional breakdown of pre- existing rocks. Epiclasts are lithic clasts and minerals released by weathering processes, and volcanic epiclasts are particles generated by the erosion of volcanic formations. Mixed volcaniclastic rocks with primary and epiclastic components are described using the terms sandstone, siltstone, and claystone, depending on their grain size, with component modifiers to provide additional information about their lithology. For example, a sand-sized deposit consisting of $20 \%$ epiclastic basalt fragments, $50 \%$ altered sideromelane shards, and $30 \%$ biogenic components would be called either a sideromelane sandstone or a volcaniclastic sandstone. The term hyaloclastite is used for fine-grained deposits consisting primarily of sideromelane shards.

\section{Volcaniclastic Components}

Volcaniclastic components are the dominant silt- to sand-sized particles in the flow deposits and include altered glass, rock fragments of basaltic to felsic compositions, and crystals of pyroxene, 


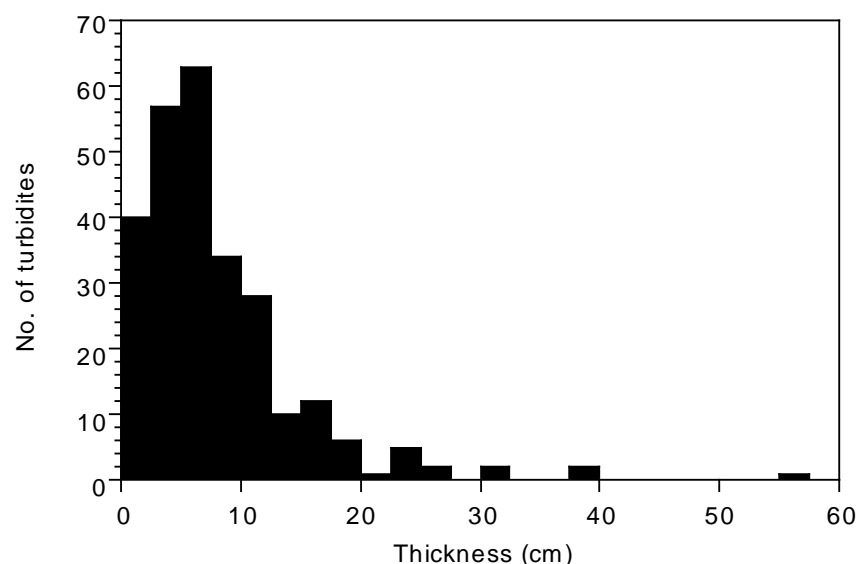

Figure 3. Histogram of the distribution of sediment gravity flow deposit thicknesses in Unit V of Site 953 . Note the prominent peak between 6 and 8 $\mathrm{cm}$.

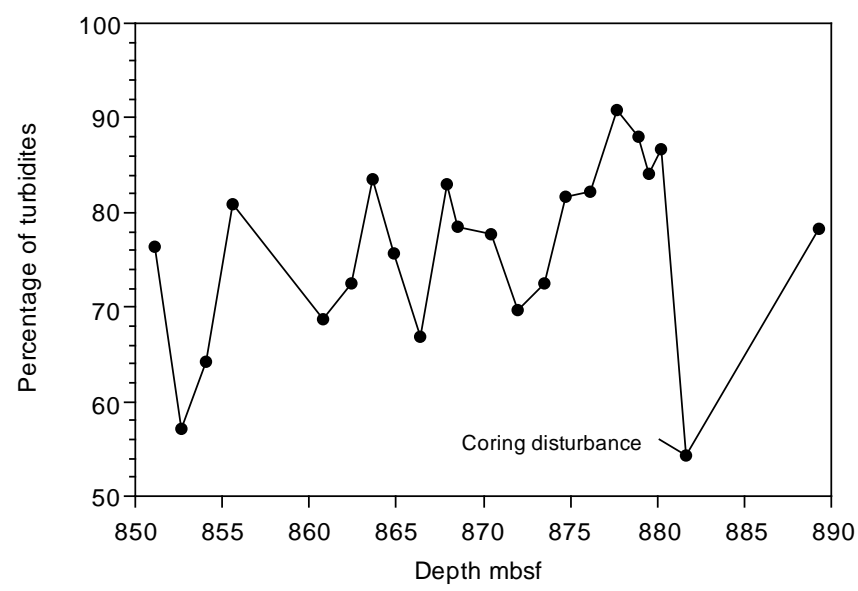

Figure 4. Thickness percentage of turbidites per core section as a function of sub-bottom depth in Unit V at Site 953. Percentages have been calculated based on a normalization for core recovery.

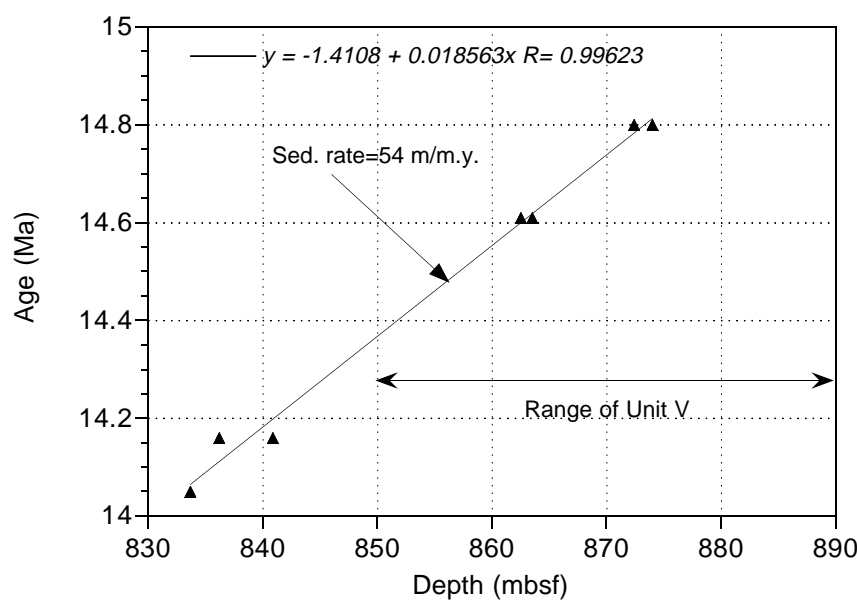

Figure 5. Age vs. depth relation for sedimentary sequences overlapping Unit $\mathrm{V}$ at Site 953. Datum levels (solid triangles) are from C. Brunner (pers. comm., 1996).
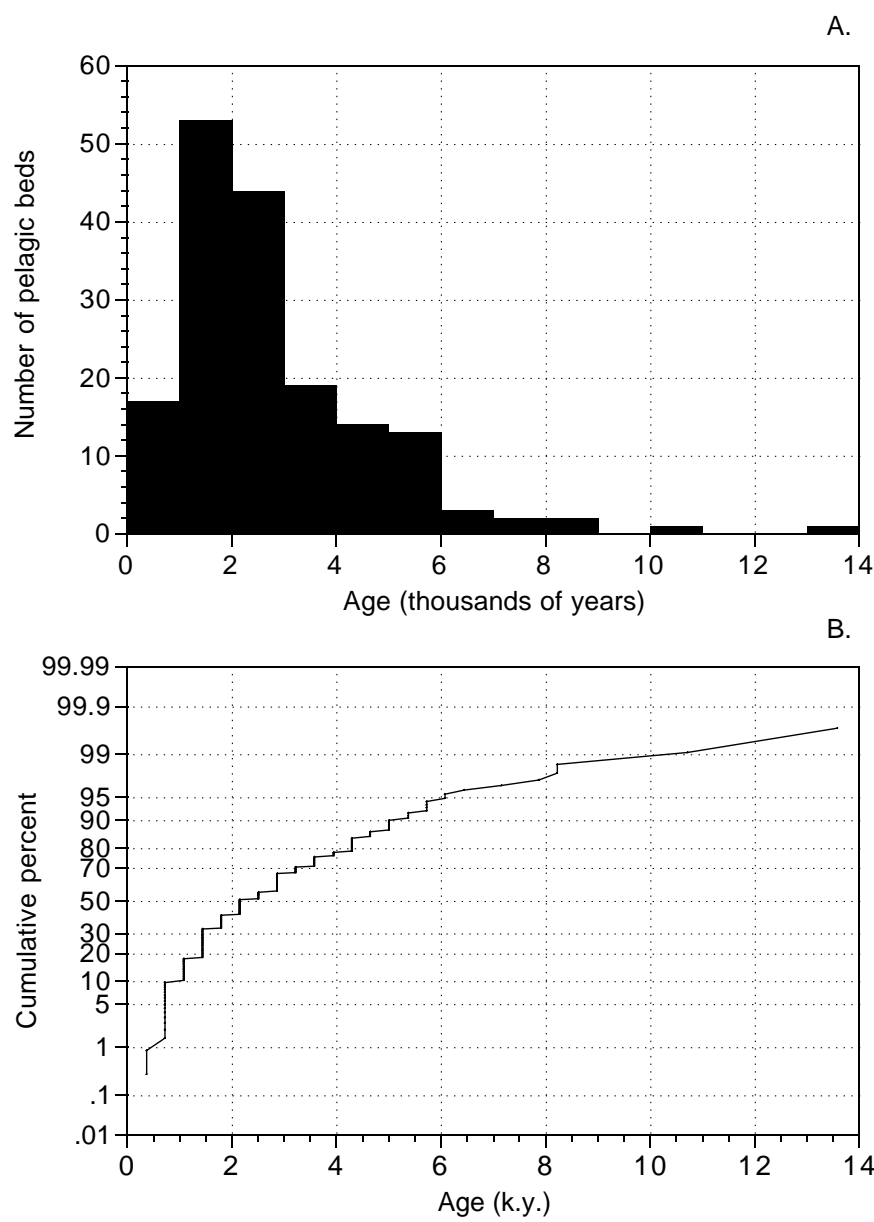

Figure 6. A. Histogram of the age intervals between sediment gravity flow events in Unit V at Site 953. Ages are based on the amount of interbedded pelagic sediment and an assumed pelagic sedimentation rate of $14 \mathrm{~m} / \mathrm{m} . \mathrm{y}$. B. Cumulative percentage plot of the age intervals between sediment gravity flow deposits. The median age interval is $\sim 2000 \mathrm{yr}$.

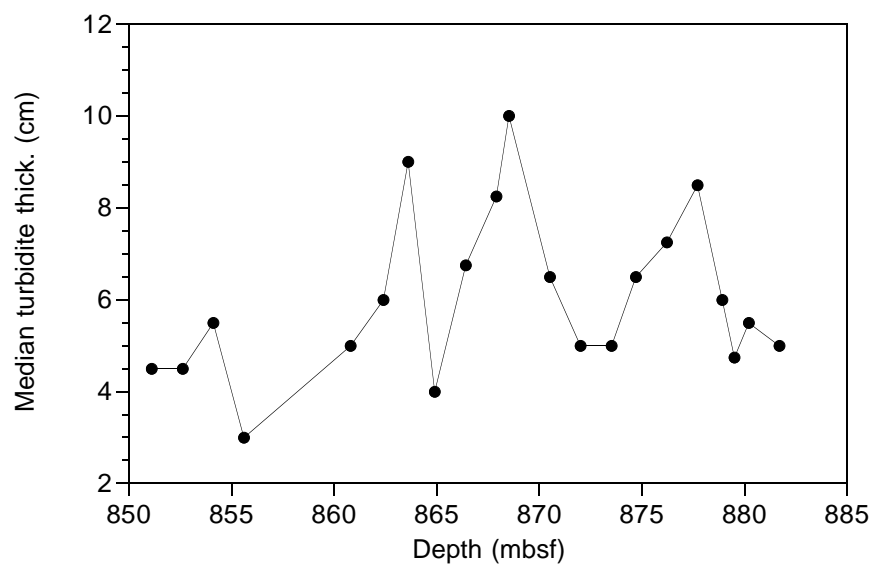

Figure 7. Median thickness of sediment gravity flow deposits per section as a function of sub-bottom depth in Unit V, Site 953. 


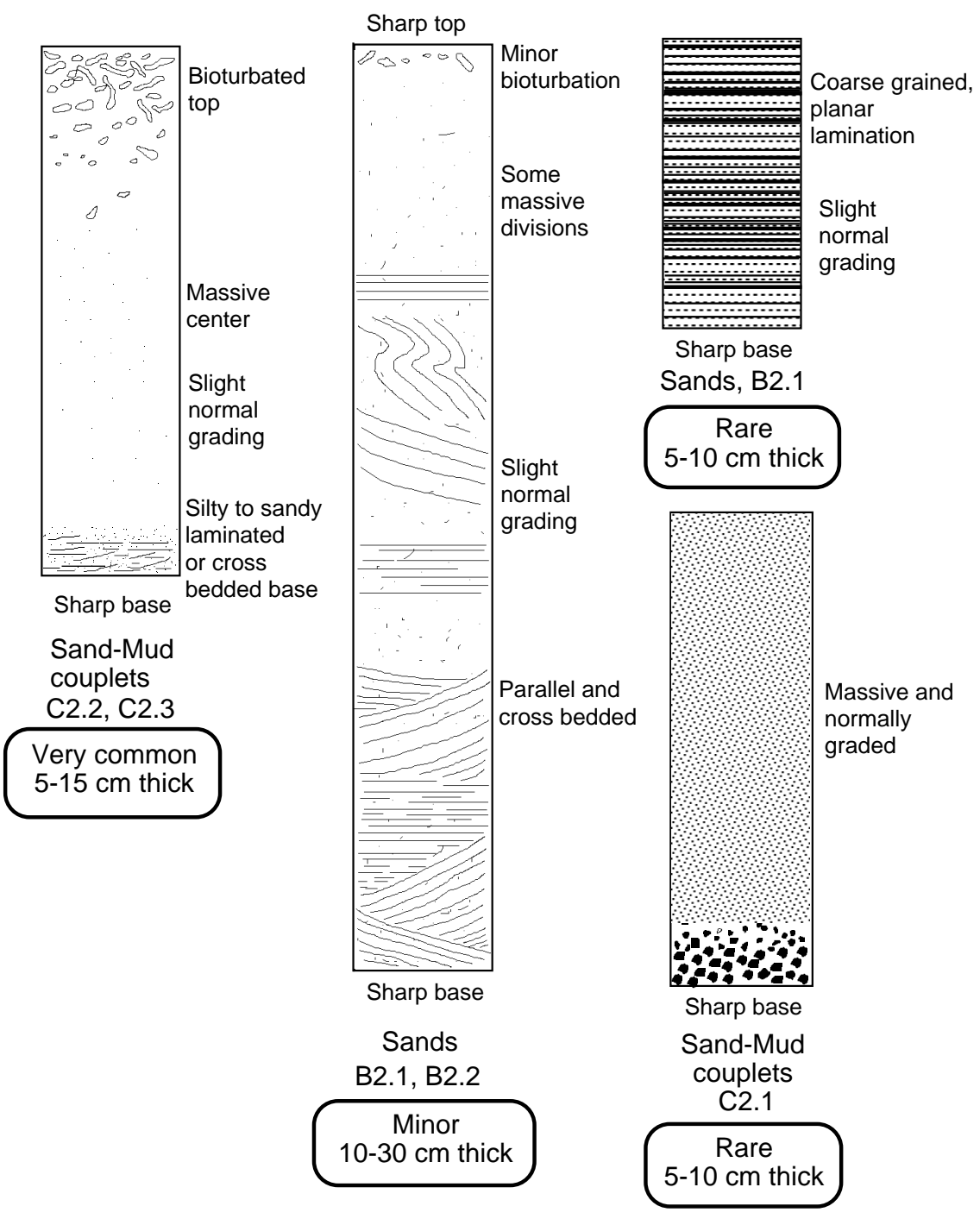

Figure 8. Examples of the major sedimentary features of sediment gravity flow deposits in Unit V, Site 953. At the base of each example is a classification (e.g., sand-mud couplet, $\mathrm{C} 2.2, \mathrm{C} 2.3$ ) of the deposit, based on the facies model of Pickering et al. (1989). feldspar, Fe-Ti oxides, biotite, and amphibole. Some volcaniclastic components are also found in the pelagic interbeds, but these are too small and scarce for detailed description.

\section{Sideromelane}

We follow the protocol of Schmincke and von Rad (1979) in using the term sideromelane to refer to altered, pseudomorphed clasts that appear originally to have been mafic glassy shards (Pl. 2). Most of the sideromelane shards show blocky morphology with curvilinear boundaries. However, some samples have a significant proportion of highly vesicular, thin-walled sideromelane clasts. Despite its alteration, sideromelane can be recognized by the angular morphologies characteristic of glassy shards, as well as the common occurrence of a thin rim of secondary minerals (Fe-Ti oxides and clay) along the shard margins.

\section{Tachylite}

Tachylite fragments generally make up some of the larger grains in the samples, reaching $1 \mathrm{~mm}$ in diameter. Like sideromelane, tachylite is characterized by an angular and sometimes vesiculated morphology ( $\mathrm{Pl} .2$ ). However, many of the tachylite fragments exhibit a greater degree of rounding than do sideromelane in the same sam- ple. Tachylite is also distinct in that it is predominantly opaque, ranging in color from dark orange through dark brown to black, and frequently contains microphenocrysts of plagioclase, clinopyroxene, and Fe-Ti oxides. In some, the abundance of crystals approaches that of crystalline rock fragments, making differentiation difficult. Although some tachylite fragments contain one or two vesicles, more vesicular fragments are rare.

\section{Clinopyroxene}

Clinopyroxene is found in all samples and is the most abundant crystal phase. It is also a frequent component of small crystalline rock fragments. The crystals are typically anhedral, relatively unaltered, and reach lengths of $\sim 1 \mathrm{~mm}$ in the coarser grained samples (Pl. 2). In plane light, the clinopyroxene is characteristically very pale green in color.

\section{Feldspar}

Feldspar is rarely present. It is most abundant in coarser grained samples, but this may simply reflect greater difficulty in identifying smaller crystals in an altered matrix. It is most frequently encountered as single, anhedral crystals of plagioclase (Pl. 2). Potassium feldspar is present in the finer grained matrix. 
Table 1. Modal analysis, Site 953C.

\begin{tabular}{|c|c|c|c|c|c|c|c|c|c|c|c|c|c|c|c|c|c|c|c|}
\hline $\begin{array}{l}\text { Core, section: } \\
\text { Interval }(\mathrm{cm})\end{array}$ & $\begin{array}{l}71 \mathrm{R}-1 \\
92-94\end{array}$ & $\begin{array}{l}71 \mathrm{R}-1 \\
94-95\end{array}$ & $\begin{array}{c}\text { 71R-1 } \\
137-139\end{array}$ & $\begin{array}{l}71 \mathrm{R}-2 \\
95-97\end{array}$ & $\begin{array}{c}71 R-2 \\
145-147\end{array}$ & $\begin{array}{r}71 \mathrm{R}-3 \\
12-14\end{array}$ & $\begin{array}{l}71 R-1 \\
92-94\end{array}$ & $\begin{array}{l}71 \mathrm{R}-4 \\
10-12\end{array}$ & $\begin{array}{l}71 \mathrm{R}-4 \\
59-61\end{array}$ & $\begin{array}{c}71 \mathrm{R}-4 \\
112-113\end{array}$ & $\begin{array}{l}71 \mathrm{R}-5 \\
10-12\end{array}$ & $\begin{array}{l}72 \mathrm{R}-1 \\
13-15\end{array}$ & $\begin{array}{l}72 \mathrm{R}-1 \\
45-47\end{array}$ & $\begin{array}{l}72 \mathrm{R}-1 \\
93-95\end{array}$ & $\begin{array}{c}72 R-1 \\
143-145\end{array}$ & $\begin{array}{c}72 R-2 \\
6-8\end{array}$ & $\begin{array}{c}72 \mathrm{R}-2 \\
115-117\end{array}$ & $\begin{array}{l}72 R-3 \\
65-66\end{array}$ & $\begin{array}{l}72 R-3 \\
67-68\end{array}$ \\
\hline Type: & $\mathrm{T}$ & $\mathrm{P}$ & $\mathrm{T}$ & $\mathrm{T}$ & $\mathrm{T}$ & $\mathrm{T}$ & $\mathrm{T}$ & $\mathrm{T}$ & $\mathrm{P}$ & $\mathrm{T}$ & $\mathrm{T}$ & $\mathrm{T}$ & $\mathrm{T}$ & $\mathrm{T}$ & $\mathrm{P}$ & $\mathrm{T}$ & $\mathrm{T}$ & $\mathrm{T}$ & $\mathrm{P}$ \\
\hline \multicolumn{20}{|l|}{ Lith. components (\%) } \\
\hline 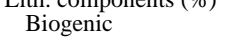 & 25.3 & 6.8 & 5.0 & 1.2 & 19.8 & 37.5 & 7.5 & 2.5 & 3.6 & 1.4 & 2.1 & 0.8 & 0.5 & 0.3 & 22.9 & 0.9 & 4.9 & 12.2 & 4.4 \\
\hline Matrix & 22.3 & 87.5 & 33.1 & 83.6 & 46.5 & 44.3 & 53.7 & 45.3 & 87.3 & 52.1 & 49.2 & 43.3 & 44.5 & 37.0 & 73.1 & 41.2 & 41.1 & 35.7 & 93.3 \\
\hline $\begin{array}{l}\text { Naturx } \\
\text { Basalt }\end{array}$ & 22.5 & 2.1 & 21.0 & $\begin{array}{r}83.0 \\
3.8\end{array}$ & $\begin{array}{r}40.3 \\
8.8\end{array}$ & $\begin{array}{r}44.3 \\
5.2\end{array}$ & 10.5 & $\begin{array}{r}45.3 \\
9.9\end{array}$ & 0.6 & 13.4 & $\begin{array}{l}49.2 \\
17.4\end{array}$ & 31.5 & 11.1 & $\begin{array}{l}37.0 \\
17.8\end{array}$ & $\begin{array}{r}15.1 \\
0.7\end{array}$ & $\begin{array}{l}41.2 \\
19.8\end{array}$ & $\begin{array}{l}41.1 \\
19.5\end{array}$ & 9.1 & 0.5 \\
\hline $\begin{array}{l}\text { Trachyte } \\
\text { Trach }\end{array}$ & 5.3 & $\begin{array}{l}2.1 \\
0.3\end{array}$ & $\begin{array}{r}21.0 \\
9.1\end{array}$ & $\begin{array}{l}3.8 \\
0.1\end{array}$ & $\begin{array}{l}0.8 \\
3.0\end{array}$ & 1.1 & 3.6 & 1.3 & $\begin{array}{l}0.0 \\
0.3\end{array}$ & $\begin{array}{r}15.4 \\
1.9\end{array}$ & $\begin{array}{r}17.4 \\
0.7\end{array}$ & $\begin{aligned} & 1.3 \\
0.3 & \end{aligned}$ & $\begin{array}{r}11.1 \\
0.6\end{array}$ & $\begin{array}{r}17.8 \\
5.9\end{array}$ & $\begin{array}{l}0.1 \\
0.0\end{array}$ & $\begin{array}{r}19.8 \\
3.3\end{array}$ & 2.4 & $\begin{array}{l}9.1 \\
0.0\end{array}$ & 0.0 \\
\hline Clinopyroxene & 4.7 & 0.3 & 3.7 & 4.5 & 7.8 & 5.2 & 10.8 & 3.4 & 2.1 & 8.3 & 5.9 & 5.9 & 8.4 & 4.1 & 1.2 & 5.1 & 3.2 & 9.3 & 0.7 \\
\hline $\begin{array}{l}\text { Feldspar } \\
\text { - }\end{array}$ & 2.7 & 0.4 & 3.3 & 0.1 & 0.1 & 0.3 & 0.3 & 0.5 & 0.3 & 0.8 & 0.2 & 0.0 & $\begin{array}{l}0.4 \\
0.9\end{array}$ & $\begin{array}{l}1.1 \\
1.6\end{array}$ & 0.5 & 0.5 & 0.4 & 2.3 & 0.0 \\
\hline Sideromelane & 3.5 & 0.3 & 8.7 & 0.0 & 0.5 & 1.5 & 1.3 & 21.6 & 0.1 & 7.9 & 8.3 & 7.2 & 27.0 & 32.9 & 0.1 & 18.9 & $\begin{array}{c}0.4 \\
19.9\end{array}$ & 16.0 & 0.0 \\
\hline Vesic. sideromelane & 1.1 & 0.0 & 0.5 & 0.0 & 0.0 & 0.0 & 0.1 & $\begin{array}{r}1.0 \\
4.1\end{array}$ & 0.0 & 0.7 & $\begin{array}{l}0.3 \\
1.0\end{array}$ & 1.0 & $\begin{array}{r}0.4 \\
0.4\end{array}$ & 0.1 & 0.0 & 0.5 & 2.1 & $\begin{array}{r}10.0 \\
0.3\end{array}$ & 0.0 \\
\hline Tachylite & 11.9 & 1.9 & 14.9 & 5.2 & 12.1 & 5.1 & 10.9 & 10.9 & 4.6 & 11.8 & 14.3 & 9.6 & 5.9 & 11.8 & 1.5 & 9.4 & 5.9 & 14.4 & 0.8 \\
\hline Vesic. tachylite & 0.2 & 0.0 & 0.3 & 0.0 & 0.2 & 0.0 & 0.0 & 0.1 & 0.0 & 0.7 & 0.3 & 0.1 & 0.0 & 0.0 & 0.0 & 0.1 & 0.3 & 0.1 & 0.0 \\
\hline $\mathrm{Fe} / \mathrm{Ti}$ oxides & 0.1 & 0.5 & 0.5 & 1.5 & 1.1 & 0.7 & 0.9 & 0.1 & 1.1 & 0.9 & 0.6 & 0.5 & 0.7 & 0.2 & 0.1 & 1.3 & 0.1 & 0.5 & 0.3 \\
\hline Biotite & 0.3 & 0.0 & 0.0 & 0.0 & 0.1 & 0.1 & 0.3 & 0.3 & 0.0 & 0.2 & 0.1 & 0.0 & 0.0 & 0.0 & 0.0 & 0.1 & 0.2 & 0.1 & 0.0 \\
\hline Amphibole & 0.1 & 0.0 & 0.0 & 0.0 & 0.0 & 0.0 & 0.1 & 0.0 & 0.0 & 0.0 & 0.0 & 0.0 & 0.0 & 0.1 & 0.0 & 0.0 & 0.0 & 0.0 & 0.0 \\
\hline Total rock frag. (\%) & 27.8 & 2.3 & 30.1 & 3.9 & 11.8 & 6.3 & 14.1 & 11.2 & 0.9 & 15.3 & 18.1 & 31.6 & 11.7 & 21.2 & 0.7 & 22.9 & 21.9 & 9.1 & 0.5 \\
\hline Total crystals (\%) & 7.8 & 1.3 & 7.6 & 6.1 & 9.1 & 6.1 & 12.5 & 4.3 & 3.5 & 10.2 & 6.7 & 6.4 & 10.0 & 5.4 & 1.8 & 6.9 & 3.9 & 12.2 & 0.9 \\
\hline Total sideromelane (\%) & 4.6 & 0.3 & 9.1 & 0.0 & 0.5 & 1.5 & 1.4 & 25.7 & & 8.6 & 9.3 & 8.2 & $\begin{array}{l}27.0 \\
27.4\end{array}$ & 29 & 0.1 & 19.2 & 22.0 & 16.3 & 0.0 \\
\hline Total tachylite $(\%)$ & 12.1 & 1.9 & 15.2 & 5.2 & 12.3 & 5.0 & $\begin{array}{l}1.4 \\
10.9\end{array}$ & 11.1 & 4.6 & 12.5 & 14.6 & $\begin{array}{l}0.2 \\
9.7\end{array}$ & $\begin{array}{r}5.4 \\
5.9\end{array}$ & 10.5 & $\begin{array}{l}.1 \\
1.5\end{array}$ & 9.4 & 6.2 & 14.5 & 0.8 \\
\hline Max. grain size $(\mu \mathrm{m})$ & 268.4 & & 526.4 & 118.0 & 239.6 & 100.3 & 151.8 & 681.2 & & 285.1 & 274.9 & 605.6 & & 440.1 & & 503.4 & 462.5 & 257.8 & \\
\hline Depth (mbsf) & 851.32 & 851.34 & 851.77 & 852.84 & 853.34 & 853.49 & 854.29 & 854.97 & 855.46 & 855.99 & 856.13 & 860.23 & 860.55 & 861.03 & 861.53 & 861.66 & 862.75 & 863.49 & 863.51 \\
\hline Unit thickness $(\mathrm{cm})$ & 4.5 & 8.5 & 39 & 12 & 7 & 12 & 9.5 & 39 & 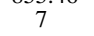 & 30 & 66 & 17 & 10.5 & 9 & 0. & 8 & 9.5 & 19 &  \\
\hline
\end{tabular}

Notes: $\mathrm{T}=$ turbidite, $\mathrm{P}=$ pelagic, Max. grain size $=$ average of 10 largest tachylite grains on slide. Lith. $=$ lithologic, Vesic.$=$ vesicular, frag. $=$ fragments.

Table 1 (continued).

\begin{tabular}{|c|c|c|c|c|c|c|c|c|c|c|c|c|c|c|c|c|c|c|c|}
\hline Core, section: & 72R-3 & 72R-4 & $72 \mathrm{R}-4$ & $72 R-5$ & 72R-5 & $72 \mathrm{R}-5$ & $72 \mathrm{R}-6$ & $72 \mathrm{R}-6$ & $72 \mathrm{R}-6$ & 72R-7 & 73R-1 & 73R-1 & 73R-1 & 73R-2 & 73R-2 & 73R-2 & 73R-3 & 73R-3 & 73R-3 \\
\hline Interval (cm): & 109-111 & $23-25$ & $108-110$ & $63-65$ & $85-87$ & $91-92$ & $15-17$ & $60-62$ & $75-77$ & $10-12$ & $31-33$ & 93-95 & $104-105$ & $70-71$ & $79-81$ & $148-150$ & $40-42$ & $77-78$ & $127-129$ \\
\hline Type: & $\mathrm{T}$ & $\mathrm{T}$ & $\mathrm{T}$ & $\mathrm{T}$ & $\mathrm{T}$ & $\mathrm{P}$ & $\mathrm{T}$ & $\mathrm{T}$ & $\mathrm{T}$ & $\mathrm{T}$ & $\mathrm{T}$ & $\mathrm{T}$ & $\mathrm{P}$ & $\mathrm{T}$ & $\mathrm{T}$ & $\mathrm{T}$ & $\mathrm{T}$ & $\mathrm{P}$ & $\mathrm{T}$ \\
\hline \multicolumn{20}{|l|}{ Lith. components (\%) } \\
\hline Biogenic & 4.7 & 3.5 & 1.7 & 6.2 & 0.7 & 13.5 & 8.1 & 12.1 & 44.5 & 0.7 & 0.7 & 1.9 & 8.5 & 2.1 & 0.3 & 10.3 & 0.9 & 25.5 & 0.0 \\
\hline Matrix & 52.8 & 37.0 & 47.7 & 43.7 & 38.9 & 84.8 & 71.3 & 46.3 & 33.3 & 57.7 & 49.2 & 68.9 & 88.9 & 41.1 & 97.6 & 56.7 & 47.7 & 70.6 & 41.3 \\
\hline Basalt & 10.7 & 13.9 & 15.2 & 10.1 & 16.5 & 0.3 & 3.9 & 4.7 & 7.5 & 11.4 & 16.3 & 6.5 & 1.3 & 11.9 & 0.2 & 8.5 & 17.9 & 0.7 & 14.1 \\
\hline Trachyte & 0.0 & 0.9 & 0.0 & 0.1 & 4.7 & 0.0 & 0.0 & 0.4 & 0.9 & 0.1 & 0.3 & 0.1 & 0.0 & 0.7 & 0.0 & 0.5 & 0.5 & 0.1 & 0.0 \\
\hline Clinopyroxene & 5.7 & 6.2 & 8.5 & 2.7 & 4.0 & 0.6 & 4.3 & 11.4 & 4.4 & 9.5 & 6.1 & 9.1 & 0.5 & 3.2 & 0.4 & 10.1 & 9.2 & 1.1 & 5.0 \\
\hline Feldspar & 0.1 & 0.9 & 0.3 & 0.1 & 2.7 & 0.2 & 0.1 & 4.7 & 0.1 & 1.1 & 0.0 & 0.3 & 0.0 & 1.9 & 0.0 & 1.1 & 0.9 & 0.4 & 0.1 \\
\hline Sideromelane & 16.7 & 32.4 & 16.1 & 24.1 & 22.9 & 0.0 & 4.1 & 9.7 & 6.3 & 11.9 & 21.4 & 6.7 & 0.0 & 29.5 & 0.0 & 5.9 & 15.7 & 0.3 & 31.7 \\
\hline Vesic. sideromelane & 0.2 & 0.5 & 0.2 & 7.6 & 0.8 & 0.0 & 0.0 & 0.3 & 0.2 & 0.4 & 0.8 & 0.0 & 0.0 & 1.7 & 0.0 & 0.1 & 0.0 & 0.0 & 0.6 \\
\hline Tachylite & 8.9 & 4.7 & 10.4 & 5.3 & 8.7 & 0.9 & 7.4 & 11.4 & 2.7 & 6.5 & 5.1 & 5.1 & 0.7 & 7.8 & 0.4 & 5.1 & 6.8 & 1.1 & 7.5 \\
\hline Vesic. tachylite & 0.1 & 0.0 & 0.0 & 0.0 & 0.0 & 0.0 & 0.0 & 0.1 & 0.0 & 0.0 & 0.0 & 0.0 & 0.0 & 0.1 & 0.0 & 0.0 & 0.0 & 0.0 & 0.0 \\
\hline $\mathrm{Fe} / \mathrm{Ti}$ oxides & 0.2 & 0.1 & 0.0 & 0.1 & 0.4 & 0.3 & 0.9 & 1.0 & 0.0 & 0.8 & 0.0 & 1.2 & 0.1 & 0.1 & 1.0 & 1.7 & 0.6 & 0.2 & 0.0 \\
\hline Biotite & 0.0 & 0.0 & 0.0 & 0.0 & 0.0 & 0.0 & 0.0 & 0.1 & 0.0 & 0.0 & 0.0 & 0.0 & 0.0 & 0.0 & 0.0 & 0.0 & 0.0 & 0.0 & 0.0 \\
\hline Amphibole & 0.0 & 0.0 & 0.0 & 0.0 & 0.0 & 0.0 & 0.0 & 0.0 & 0.0 & 0.0 & 0.0 & 0.0 & 0.0 & 0.0 & 0.0 & 0.0 & 0.0 & 0.0 & 0.0 \\
\hline Total rock frag. (\%) & 10.7 & 14.7 & 15.2 & 10.2 & 21.2 & 0.3 & 3.9 & 5.0 & 8.4 & 11.5 & 16.7 & 6.6 & 1.3 & 12.7 & 0.2 & 9.0 & 18.3 & 0.9 & 14.0 \\
\hline Total & 50 & 72 & 8 & 2.9 & 7.1 & 1.1 & 5.3 & 16.8 & 4.5 & 11.4 & 6. & 10.7 & 0. & 5.2 & 1.4 & 12.9 & 10.7 & 1.7 & 5.1 \\
\hline Total sideromelane (\%) & 16.9 & 32.9 & 16.3 & 31.7 & 23.6 & 0.0 & 4.1 & 9.7 & 6.5 & 12.3 & 22.2 & 6.7 & 0.0 & 31.1 & 0.0 & 6.1 & 15.7 & 0.3 & 32.2 \\
\hline Total tachylite (\%) & 8.9 & 4.7 & 10.4 & 5.3 & 8.6 & 0.9 & 7.4 & 11.3 & 2.7 & 6.5 & 5.1 & 5.1 & 0.7 & 7.9 & 0.4 & 5.1 & 6.8 & 1.1 & 7.5 \\
\hline Max. grain size $(\mu \mathrm{m})$ & 256.6 & 250.7 & 229.9 & 311.2 & 644.1 & & 90.0 & 123.1 & 183.2 & 105.3 & & 85.6 & & 258.2 & & 118.8 & 170.5 & & 292.9 \\
\hline Depth (mbsf) & 863.93 & 864.38 & 865.23 & 866.28 & 866.5 & 866.56 & 867.28 & 867.73 & 867.88 & 868.49 & 870.01 & 870.63 & 870.74 & 871.9 & 871.99 & 872.68 & 873.1 & 873.47 & 873.97 \\
\hline Unit thickness (cm) & 17.5 & 25.5 & 15.5 & 30 & 16.5 & 4 & 8.5 & 55.5 & 55.5 & 7 & 11 & 6.5 & 4.5 & 18.5 & 4 & 18 & 5.5 & 4.5 & 21.5 \\
\hline
\end{tabular}




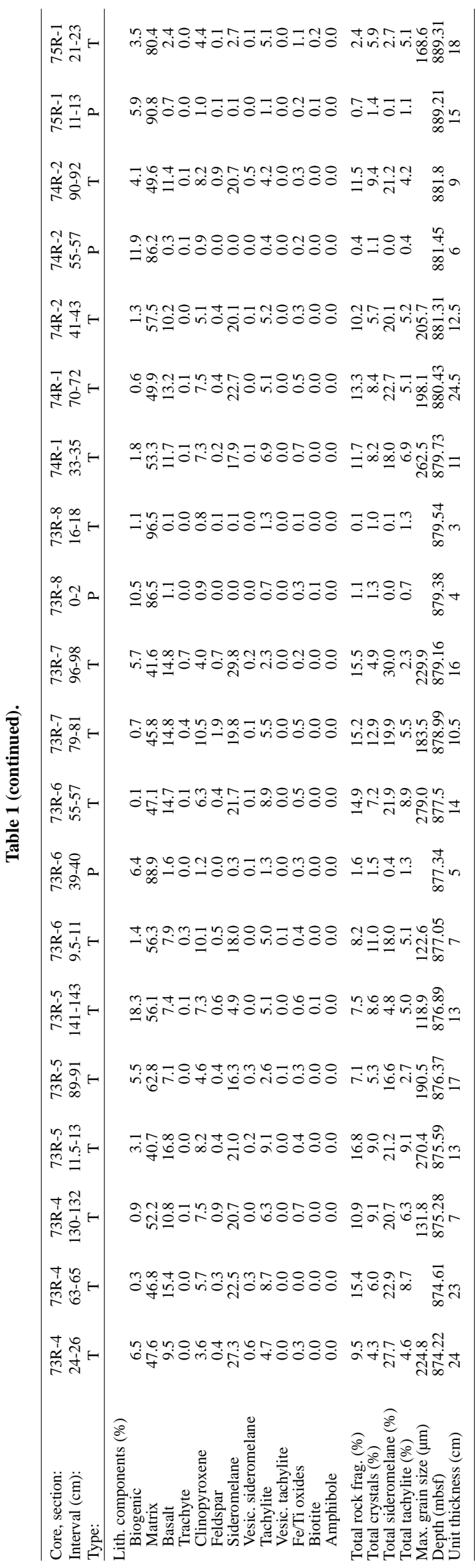

\section{Fe-Ti Oxides}

Although Fe-Ti oxides are abundant within rock fragments and tachylite clasts, their occurrence as free crystals is less common. When found as isolated crystals, they are typically equidimensional and very fine grained $(<50 \mu \mathrm{m})$ and are possibly secondary alteration products within the matrix (Pl. 2).

\section{Minor Crystal Phases}

Minor amounts of biotite and amphibole $(<0.5 \%)$ are present in some of the flow deposits. Crystals are typically anhedral and range in size from $100-300 \mu \mathrm{m}$.

\section{Igneous Rock Fragments}

Igneous rock fragments are often the largest grains within a sample (as large as $1 \mathrm{~mm}$ in diameter) and are frequently well rounded and oval in shape ( $\mathrm{Pl}$. 2). Basaltic fragments are dominant and typically contain plagioclase, clinopyroxene, and Fe-Ti oxides in the form of microlites, as well as microphenocrysts. The less common felsic grains are primarily plagioclase and $\mathrm{Fe}-\mathrm{Ti}$ oxides. Basaltic and felsic fragments are typically very fine grained and exhibit a variety of petrographic textures. Most frequently, microphenocrysts of clinopyroxene and/or plagioclase are found in an intergranular matrix of feldspar laths and numerous, small, opaque granules. Pilotaxitic textures are also common, whereas subophitic and ophitic textures were not observed.

\section{Biogenic Components}

The dominant biogenic clasts are skeletal fragments of foraminifers and nannofossils (Pl. 3), although some samples contain neritic bioclasts. Occasional sedimentary clasts resembling the matrix material are also present.

\section{Alteration of Volcanogenic Components}

To characterize the matrix and the general nature and degree of alteration of volcanogenic components, X-ray diffraction (XRD) was carried out on 10 untreated bulk samples (Table 2). EDS was used on thin sections to examine the alteration of sideromelane clasts. XRD analysis supplements the petrographic observations by adding insight into the makeup of the matrix component of the turbidites. Emphasis was placed on estimating the carbonate, clay, and fine-grained volcanogenic component content of the matrix.

The relative percentage of carbonate in the turbidites was estimated by comparison to a control clay with $2 \%, 5 \%$, and $10 \%$ added calcium carbonate. Calcium carbonate content in the turbidites, based on comparison to these mixtures, is low, ranging from a trace to $\sim 5 \%-$ $7 \%$. These results are generally comparable to modal estimates of the coarse biogenic detritus in the samples.

Modal and XRD results indicate clinopyroxene (cpx) is the most abundant igneous mineral. Cpx is pervasive; its abundance is estimated to be $\sim 10 \%(\sim 15 \times)$ of the maximum estimate from petrography for the samples investigated by XRD. Errors are inherently large, however, for XRD estimates of mineral abundance (Bayliss, 1986). Also pervasive is plagioclase feldspar, with abundances higher than that determined petrographically $(0.1 \%-3.3 \%$ for the samples investigated), indicating that it may be as abundant in the matrix as it is in coarser sized fractions. Alternatively, plagioclase in clasts of microcrystalline basalt may contribute to the signal. The only other igneous mineral identified is Fe-Ti oxide, whose content is low and near the detection limit (1\%) for the XRD method.

Sideromelane shards provide direct evidence of the transformation of basaltic glass to clay and other products. These pseudomorphed, 
Table 2. Summary of XRD and EDS analyses, Site 953C.

\begin{tabular}{|c|c|c|c|c|c|c|c|c|c|}
\hline $\begin{array}{l}\text { Core, section, } \\
\text { interval }(\mathrm{cm})\end{array}$ & Sample type & Analysis & $\begin{array}{c}\% \\
\text { Matrix }\end{array}$ & Smectite & $\mathrm{I} / \mathrm{S}$ & $\begin{array}{c}\mathrm{XRD} \\
\mathrm{CaCO}_{3}\end{array}$ & $\begin{array}{c}\% \\
\text { Cpx }\end{array}$ & $\begin{array}{l}\% \\
\text { Fsp }\end{array}$ & $\begin{array}{c}\% \\
\text { Basalt }\end{array}$ \\
\hline \multicolumn{10}{|l|}{ 157-953C- } \\
\hline 71R-1, 137-139 & Bulk & XRD & 33 & Yes & ND & $<10$ & Mod & High & 21.0 \\
\hline $71 \mathrm{R}-5,10-12$ & Bulk & XRD & 49 & Yes & ND & $<2$ & High & Mod & 17.4 \\
\hline 72R-2, 115-117 & Bulk & XRD & 41 & Yes & ND & $<10$ & High & High & 19.5 \\
\hline $72 \mathrm{R}-5,63-65$ & Bulk & XRD & 44 & Yes & ND. & $<10$ & Mod/low & Low & 10.1 \\
\hline $72 \mathrm{R}-5,85-87$ & Bulk & XRD & 39 & Yes & ND & $<2$ & Mod & High & 16.5 \\
\hline $73 \mathrm{R}-1,31-33$ & Bulk & XRD & 50 & Yes & ND & $<2$ & Mod & Mod & 16.3 \\
\hline $73 \mathrm{R}-3,127-129$ & Bulk & XRD & 41 & Yes & ND & $<<2$ & Mod & High & 14.1 \\
\hline $73 \mathrm{R}-6,55-57$ & Bulk & XRD & 47 & Yes & ND & $<2$ & High & Mod/low & 14.7 \\
\hline $74 \mathrm{R}-1,70-72$ & Bulk & XRD & 50 & Yes & ND & $<<2$ & High & Mod & 13.2 \\
\hline $74 \mathrm{R}-2,41-43$ & Bulk & XRD & 58 & Yes & ND & $<2$ & $\mathrm{ND}$ & Very low & 10.2 \\
\hline 72R-1, 45-47 & Thin section & EDS & 45 & Yes & Yes & NA & NA & & \\
\hline $73 \mathrm{R}-1,31-33$ & Thin section & EDS & 50 & Yes & Yes & Above & NA & & \\
\hline 73R-3, 127-129 & Thin section & EDS & 41 & Yes & ? & Above & NA & & \\
\hline $73 R-4,63-65$ & Thin section & EDS & 47 & Yes & Yes & NA & NA & NA & \\
\hline
\end{tabular}

Notes: Bulk = bulk sample. $\%$ matrix from modal table. Smectite $=$ smectite recognized on basis of peak near $6^{\circ}$ (see text). I/S $=$ mixed-layer, illite-smectite on basis of EDS chemistry $\left(\mathrm{ND}=\right.$ not determined), $\mathrm{XRD} \mathrm{CaCO}_{3}=$ relative percentage of carbonate based on methodology described in text. \% Cpx $=$ abundance of clinopyroxene based on $\mathrm{XRD}$ (high $=$ $\sim 10 \%, \bmod =5 \%-10 \%$, low $=<5 \%, \mathrm{NA}=$ not applicable) $\% \mathrm{Fsp}=$ abundance of feldspar based on combined height of cpx + fsp peak near $27^{\circ} 2 \theta($ high $=\sim 5 \%$, mod $=2 \%-5 \%$, low $=<2 \%$ ). Bulk = bulk sample. $\mathrm{ND}=$ not determined.

former basaltic glass shards, now consist of clay and Fe-Ti oxide (Tirich), the latter exclusively as rims along former shard margins. Schmincke and von Rad (1979) describe identical features developed in volcaniclastic sandstones of Deep Sea Drilling Project (DSDP) Site 397. Semiquantitative EDS analyses of sideromelane shard interiors and rims (inboard of the Fe-Ti-oxide) show subequal concentrations of $\mathrm{Mg}, \mathrm{Fe}$, and $\mathrm{Al}$; low $\mathrm{Ca}$; some $\mathrm{Cl}$; and are $\mathrm{Si}$-dominated. As such, the shards are comparable to the smectites infilling vesicles in basalt glass and forming fine aggregates in the matrix of basalt lavas, as described by Viereck et al. (1982). XRD evidence for the smectites is shown by the presence of a smectite peak in all samples at $\sim 5.6^{\circ} 2 \theta$; no special treatments (e.g., ethylene glycolation) were carried out to further characterize the smectites. EDS analyses of the extreme borders of the sideromelane shards show reduced $\mathrm{Mg}$ and $\mathrm{Fe}$ in the clay, and increased $\mathrm{K}$. The bulk chemical composition is consistent with the clays being more "illitic"; consequently, they may be mixed-layer illite/smectite (I/ S).

Thus, the matrix of the volcaniclastics may contain minor carbonate, plagioclase, and cpx approaching the abundance seen in the coarser fractions, and is devoid of glass, most likely reflecting the transformation of glass into smectite as shown by the pseudomorphed sideromelane shards. Fine-grained basalt glass would have been highly susceptible to smectitization.

\section{Modal Analysis Results}

\section{Volcaniclastic Deposits}

Modal analysis was carried out on 48 samples representing the major types of sediment gravity flows in Unit V (Table 1). The deposits consist of mixtures of five major components: altered sideromelane, tachylite, igneous rock fragments, crystals, and bioclasts. Quantitative determination of these components is difficult because of the variable amount of altered matrix and the problems associated with identifying fine-grained particles. Schmincke and von Rad (1979) encountered similar problems in their petrographic analysis of volcaniclastic sandstones recovered at Site 397 (Leg 43A), located $\sim 100 \mathrm{~km}$ south-southeast of Gran Canaria (Fig. 1). They noted that glass and some minerals are probably under-represented in the modal analysis because of their inclusion in the altered matrix. Thus, matrix values are maximums and may include as much as $10 \%-15 \%$ of the altered equivalents of originally coarse grains.

There is considerable diversity in the lithology of the flow deposits, but no distinct groupings emerge based on the proportions of components (Fig. 9). Coarse-grained deposits $(>500 \mu \mathrm{m})$ tend to have higher concentrations of igneous rock fragments and relatively low crystal contents (Fig. 9B; Pl. 3). With decreasing grain size, the de-
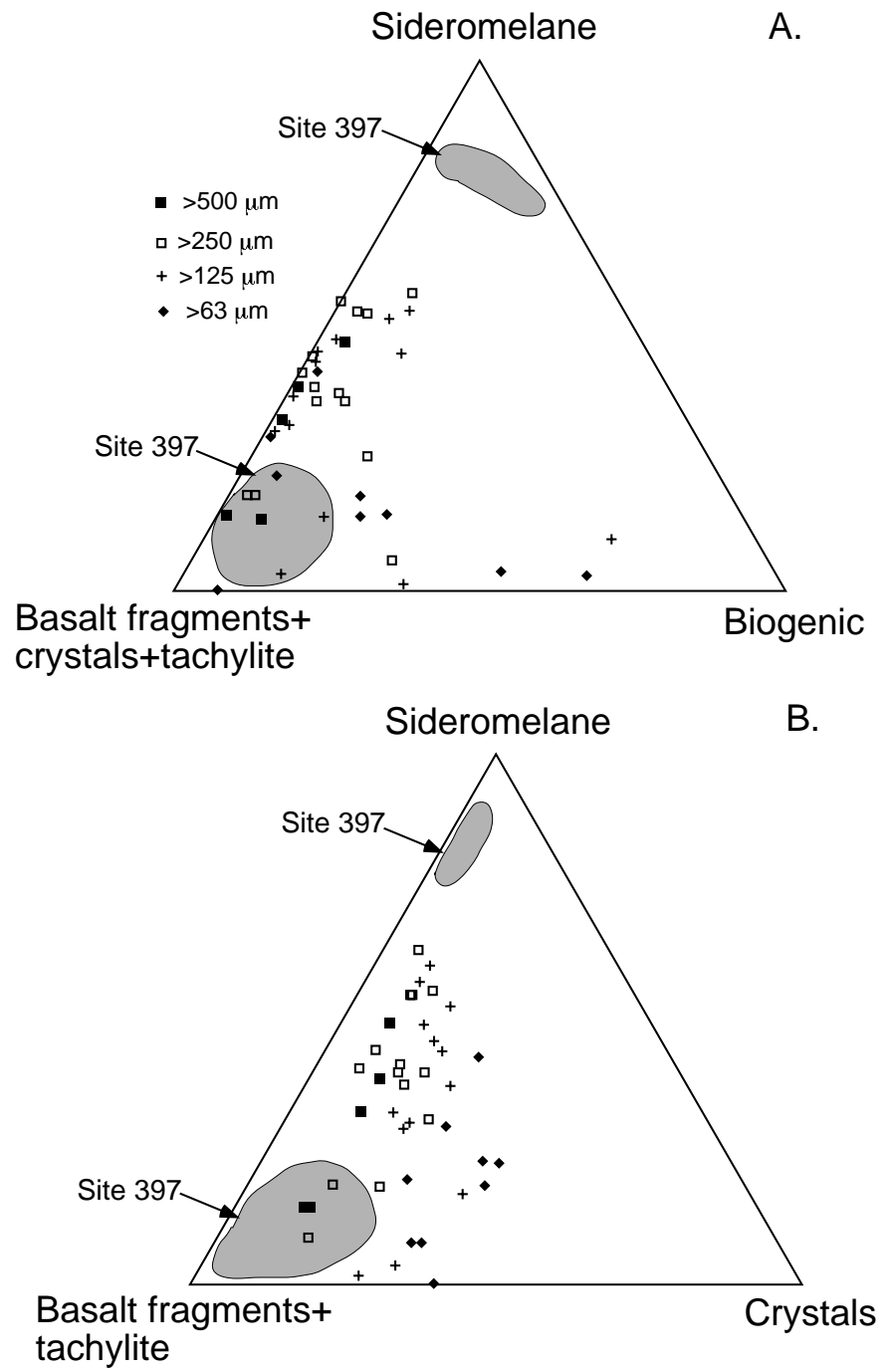

Figure 9. Ternary diagrams showing the lithology of sediment gravity flow deposits based on modal analysis of thin sections in Table 1. Samples have been grouped based on their maximum particle size. Shaded fields for Site 397 are based on data from Schmincke and von Rad (1979). 
posits exhibit a wider range in sideromelane content, an increase in the amount of crystals, and the presence of more biogenic components (Fig. 9). The data indicate that there is a continuous transition from deposits rich in igneous rock fragments and tachylite to those that are rich in sideromelane. Within this transition, there is variable dilution with nonvolcanic components (biogenic), especially in the finer grained units.

Some of the deposits in Unit V are petrographically similar to the volcaniclastic sandstones described by Schmincke and von Rad (1979) at Site 397 (Fig. 9; Pl. 3). In addition, some of the mediumgrained sandstone layers in Unit V approach the sideromelane content of the altered hyaloclastites described by these workers. However, at Site 397, the volcaniclastic sandstones and hyaloclastites form two distinct groups on ternary diagrams similar to Figure 9, whereas in Unit $\mathrm{V}$ the deposits completely fill in the area, separating these two groups. These observations emphasize the mixed character of the flow deposits in Unit V at Site 953.

In order to evaluate any temporal changes in the lithology of layers in Unit V, we have plotted the variation of tachylite and sideromelane as a function of sub-bottom depth (Fig. 10). The data exhibit considerable fluctuations because of local differences in deposit lithology and grain size, but there is a clear trend of decreasing tachylite concentration with increasing sub-bottom depth. A weaker, opposite trend is discernible in the sideromelane contents (Fig. 10). We believe the tachylite trend is a more robust signal because of the relatively unambiguous identification of these clasts compared with sideromelane clasts that are often obscured within the highly altered matrix.

\section{Pelagic Deposits}

Interbedded with the flow deposits of Unit $\mathrm{V}$ are thin intervals of nannofossil-mixed sedimentary rock, nannofossil claystone, and claystone (Pl. 3). These intervals also contain dispersed volcaniclas-
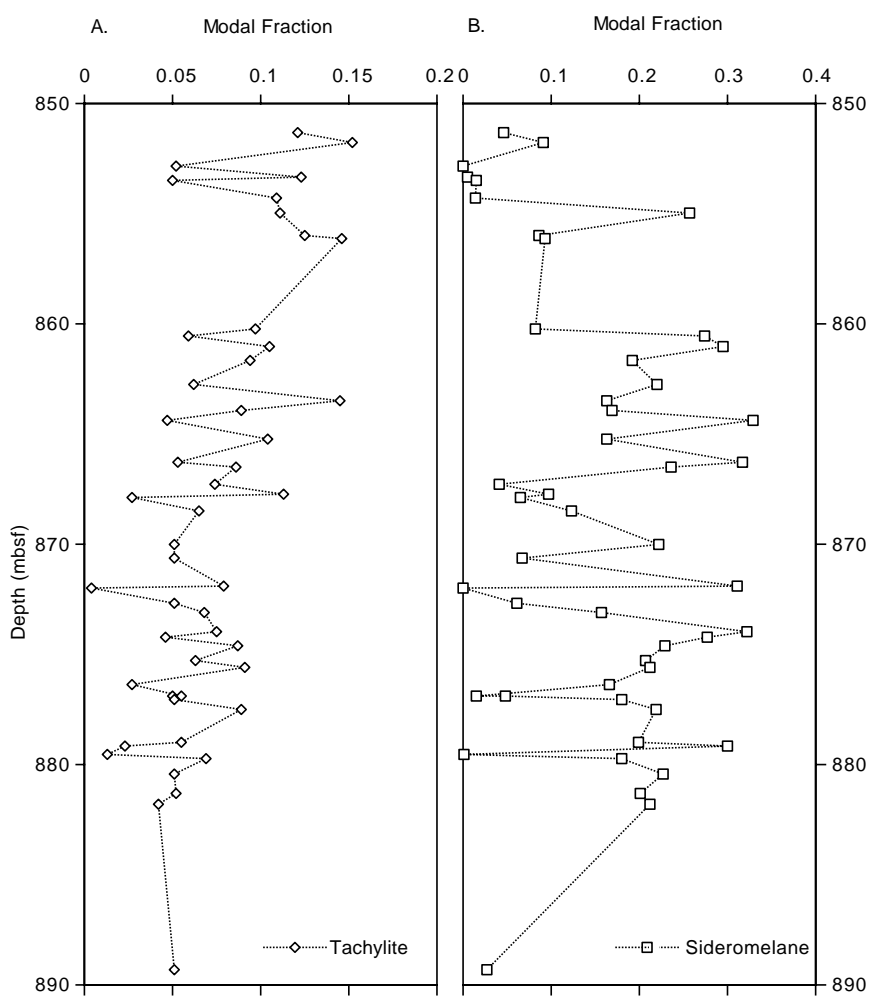

Figure 10. Modal fraction of (A) tachylite (open diamonds) and (B) sideromelane shards (open squares) as a function of sub-bottom depth in Unit V, Site 953. tic components ranging from $7 \%-29 \%$. The types of clasts are the same as those in the flow deposits, although their relative proportions are different and their grain sizes are smaller. Foraminifer fragments are the most abundant bioclast type, composing $\sim 4 \%-25 \%$ of the coarse- grained fraction of the rock.

\section{MAJOR AND TRACE ELEMENT GEOCHEMISTRY}

Major and trace element compositions of eight samples from Unit V, Site 953, were determined using a Kevex 0700/7000 energy dispersive XRF spectrometer. The results are presented in Table 3. Sample locations were chosen from the upper half $(\sim 20 \mathrm{~m})$ of the unit at $\sim 2-$ to 6-m intervals. Because the samples were collected from the turbidite layers rather than the interbedded pelagic layers, they all consist of $>50 \%$ volcaniclastic material, with the exception of Sample 157-953C-71R-4, 10-12 cm ( 19\%).

The major and trace element concentrations for the Unit V samples are plotted along with the results of shipboard analyses from Leg 157 (Figs. 11, 12). The shipboard data is for samples from lithologic Units V, VI, and VII described at Site 953. The major element data for the shipboard samples were adjusted to compensate for the presence of biogenic carbonate. It was assumed that all loss on ignition (LOI) in excess of $10 \%$ was $\mathrm{CO}_{2}$, and an equivalent amount of $\mathrm{CaO}$ was subtracted from the analysis. LOI was $<10 \%$ for all eight of the new Unit V samples, so no adjustments were made. Similarly, no adjustments were made to trace element data.

In terms of major oxides, the Unit $\mathrm{V}$ samples are characterized by low $\mathrm{SiO}_{2}(33.3 \%-49.5 \%)$ and high $\mathrm{MgO}, \mathrm{Fe}$, and $\mathrm{TiO}_{2}$. In all of the major element variation plots, the Unit $\mathrm{V}$ samples form a relatively compact cluster that overlaps with one of the two shipboard data points for Unit V. The other shipboard analyses for Unit V consistently fall nearby, but outside, the main Unit V field. The slightly anomalous behavior of this sample is probably caused by a large biogenic component, which is reflected by a high concentration of $\mathrm{CaO}$.

Trace element data indicate that Unit V is relatively enriched in compatible elements ( $\mathrm{Ni}$ and $\mathrm{Cu}$ ) and depleted in incompatible elements $(\mathrm{Zr}, \mathrm{Nb}, \mathrm{Ce}, \mathrm{Y}, \mathrm{Rb}$, and $\mathrm{Zn})$. There are no shipboard La data for comparison, but the La values for new Unit V samples are of the order of those typically associated with alkali basalts.

It is clear from the variation diagrams that the signatures of the volcaniclastic source rocks dominate the geochemical trends, despite the fact that the Site 953 samples, like most sedimentary rocks, are composed of a mixture of clastic materials. Unit V samples are dominantly mafic in composition, and trace element ratios, such as $\mathrm{Zr} / \mathrm{Nb}$, suggest a common parentage for the volcanic rocks of Units V, VI, and VII.

\section{PARTICLE MORPHOLOGY}

The shape and form of small particles provide information about their origin, transport, and depositional history (e.g., Margolis and Kennett, 1970; Krinsley and Doornkamp, 1973; Krinsley, 1985). In the case of volcaniclastic particles, morphology is useful for understanding the nature of the fragmentation process (e.g. Heiken and Wohletz, 1991; Sheridan and Marshall, 1983a, 1983b) and the extent to which particles have been reworked following volcanic events (Carey and Sigurdsson, 1978). Honnorez and Kirst (1975) proposed a discrimination of deposits formed in deep water by nonexplosive granulation (hyaloclastites) from those formed in shallow water by phreatomagmatic and phreatic eruptions (hyalotuffs). They argued that a distinction could be drawn based on morphometric parameters such as grain planarity, convexity, concavity, and number of grain corners. Planar particles having few grain corners are characteristic of hyaloclastites, whereas low planarity and a large number of grain corners are more typical of hyalotuffs. 
Table 3. Major and trace element concentrations, Site 953C.

\begin{tabular}{|c|c|c|c|c|c|c|c|c|c|c|}
\hline Core, section: & $71 \mathrm{R}-1$ & 71R-1 & $71 \mathrm{R}-4$ & $72 \mathrm{R}-1$ & 72R-1 & $72 \mathrm{R}-3$ & $72 \mathrm{R}-5$ & $72 \mathrm{R}-6$ & $73 R-2$ & $73 \mathrm{R}-3$ \\
\hline Interval $(\mathrm{cm})$ : & $92-94$ & $137-139$ & $10-12$ & 93-95 & $143-145$ & $65-66$ & $85-87$ & $60-62$ & $70-71$ & $77-78$ \\
\hline Type: & $\mathrm{T}$ & $\mathrm{T}$ & $\mathrm{T}$ & $\mathrm{T}$ & $\mathrm{P}$ & $\mathrm{T}$ & $\mathrm{T}$ & $\mathrm{T}$ & $\mathrm{T}$ & $\mathrm{P}$ \\
\hline \multicolumn{11}{|c|}{ Major elements (wt\%) } \\
\hline $\mathrm{SiO}_{2}$ & 43.10 & 48.28 & 45.39 & 46.91 & 33.32 & 46.12 & 47.73 & 45.09 & 49.45 & 34.64 \\
\hline $\mathrm{TiO}_{2}^{2}$ & 3.06 & 3.51 & 3.70 & 4.43 & 1.37 & 3.50 & 3.96 & 3.63 & 3.72 & 1.28 \\
\hline $\mathrm{Al}_{2} \mathrm{O}_{3}$ & 10.68 & 13.56 & 12.24 & 13.96 & 8.68 & 11.56 & 13.37 & 10.06 & 14.19 & 10.18 \\
\hline $\mathrm{Fe}_{2} \mathrm{O}_{3}(\mathrm{~T})$ & 12.53 & 13.11 & 13.49 & 13.80 & 3.53 & 14.23 & 14.10 & 13.61 & 11.84 & 3.08 \\
\hline $\mathrm{MnO}$ & 0.14 & 0.16 & 0.19 & 0.19 & 0.09 & 0.20 & 0.18 & 0.17 & 0.18 & 0.07 \\
\hline $\mathrm{MgO}$ & 7.32 & 6.19 & 10.09 & 7.89 & 2.80 & 10.12 & 8.48 & 9.79 & 6.79 & 1.97 \\
\hline $\mathrm{CaO}$ & 18.72 & 8.76 & 9.71 & 6.37 & 47.63 & 8.75 & 6.26 & 12.79 & 6.54 & 42.84 \\
\hline $\mathrm{Na}_{2} \mathrm{O}$ & 2.21 & 2.96 & 2.90 & 3.56 & 0.63 & 3.00 & 4.30 & 2.79 & 4.25 & 1.28 \\
\hline $\mathrm{K}_{2} \mathrm{O}$ & 1.50 & 2.21 & 1.62 & 2.17 & 3.12 & 1.25 & 1.50 & 1.57 & 2.51 & 4.42 \\
\hline $\mathrm{P}_{2} \mathrm{O}_{5}$ & 0.67 & 0.57 & 0.52 & 0.64 & 0.32 & 0.48 & 0.54 & 0.45 & 0.44 & 0.28 \\
\hline Total & 99.91 & 99.31 & 99.84 & 99.91 & 101.48 & 99.22 & 100.43 & 99.95 & 99.92 & 100.05 \\
\hline$\%$ LOI & 9.96 & 4.47 & 8 & 6.86 & 27.26 & 6.38 & 5.34 & 7.13 & 7.48 & 25.32 \\
\hline \multicolumn{11}{|c|}{ Trace elements (ppm) } \\
\hline $\mathrm{Nb}$ & 46 & 57 & 40 & 49 & 19 & 39 & 42 & 35 & 39 & 16 \\
\hline $\mathrm{Zr}$ & 280 & 316 & 250 & 276 & 209 & 216 & 254 & 239 & 217 & 115 \\
\hline $\mathrm{Y}$ & 25 & 23 & 23 & 26 & 17 & 21 & 24 & 24 & 26 & 12 \\
\hline $\mathrm{Sr}$ & 648 & 599 & 324 & 363 & 549 & 231 & 339 & 291 & 251 & 536 \\
\hline $\mathrm{Rb}$ & 23 & 27 & 15 & 18 & 46 & 10 & 15 & 14 & 34 & 45 \\
\hline $\mathrm{Zn}$ & 91 & 92 & 81 & 94 & 49 & 98 & 95 & 99 & 94 & 36 \\
\hline $\mathrm{Cu}$ & 68 & 67 & 112 & 48 & 55 & 133 & 99 & 87 & 132 & 62 \\
\hline $\mathrm{Ni}$ & 241 & 165 & 216 & 210 & 55 & 368 & 286 & 306 & 250 & 30 \\
\hline $\mathrm{Ce}$ & 94 & 93 & 83 & 92 & 64 & 80 & 76 & 73 & 73 & 50 \\
\hline $\mathrm{Ba}$ & 260 & 402 & 193 & 293 & 164 & 259 & 352 & 295 & 817 & 362 \\
\hline $\mathrm{La}$ & 46 & 43 & 42 & 44 & 40 & 31 & 37 & 34 & 28 & 24 \\
\hline
\end{tabular}

Notes: $\mathrm{T}=$ turbidite, and $\mathrm{P}=$ pelagic. $\% \mathrm{LOI}=$ percentage loss on ignition.
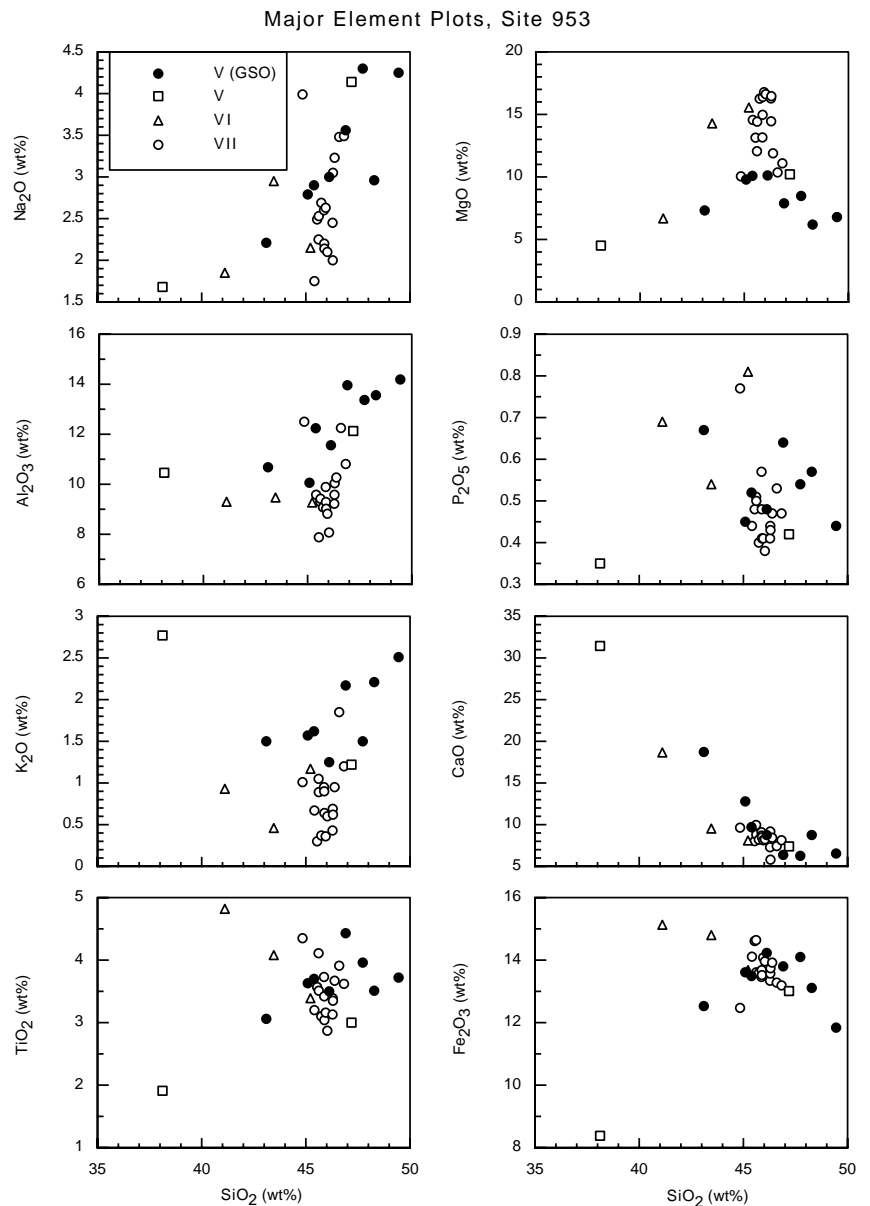

Figure 11. Major element variation diagrams plotted vs. $\mathrm{SiO}_{2}$ for volcaniclastic turbidites in Unit V, Site 953. Key to shipboard data from Shipboard Scientific Party (1995) is shown in the box.

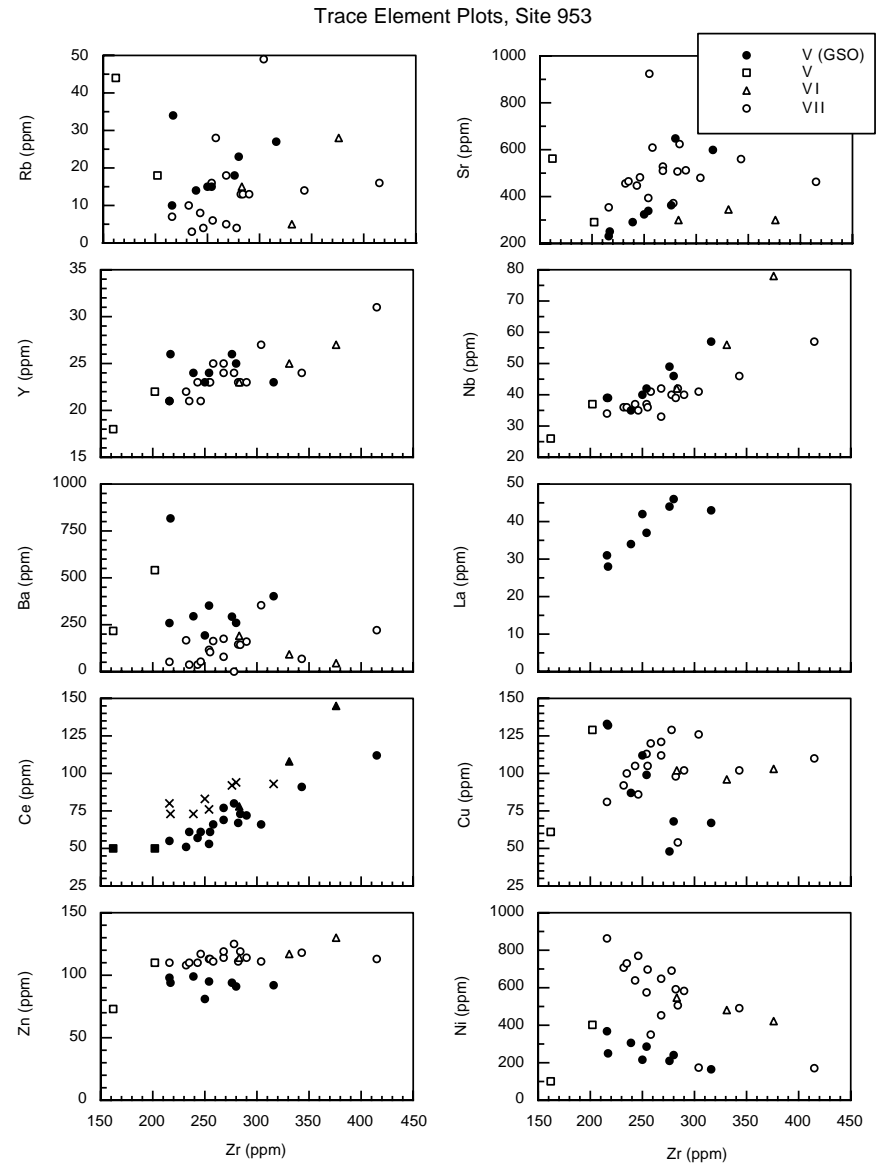

Figure 12. Trace element variation diagrams plotted vs. $\mathrm{Zr}$ for bulk volcaniclastic turbidites from Unit V, Site 953. Key to shipboard data from Shipboard Scientific Party (1995) is shown in the box. 
The morphometric measurements proposed by Honnorez and Kirst (1975) are difficult and time consuming. Furthermore, there have been new techniques developed since their paper was published that deal with the quantification of highly irregular particles. Orford and Whalley (1983) demonstrated the usefulness of fractal analysis in characterizing the morphology of irregular particle outlines, especially those that exhibit boundary reentrants. The fractal method of particle shape analysis is based on the concept that the perimeter of an irregular boundary appears to become longer as the unit of measurement becomes smaller (Mandelbrot, 1967; Kaye, 1986). As the unit of measure, or step length $(L)$, becomes smaller, the shape of the irregular boundary is more accurately approximated. The relationship between the step length $(L)$ and the perimeter length $(P)$ can be plotted as a line, by which the particle shape may be characterized. On a plot of $\log L$ vs. $\log P$, sometimes referred to as a Richardson plot (Russ, 1992), a straight line with a single slope represents a particle that has a self-similar, or true fractal, shape (i.e., morphological variations are the same at any scale). Such a particle may be described by its fractal dimension $(D)$, which is related to the slope, $S$, of the $\log L$ vs. $\log P$ plot by

$$
D=1-S
$$

Values of $D$ range from 1.0 to 2.0 , with an increasing value corresponding to a more irregular boundary. In practice, most sedimentary or volcanic particles do not exhibit true fractal behavior, but instead show a series of linear segments on a Richardson plot that are interpreted as fractal elements (Orford and Whalley, 1983). These elements include a textural fractal related to small-scale irregularities on the particle surface, and a structural fractal that describes the macroscopic morphology.

One of the objectives of our study on Unit V was to evaluate any temporal changes in the sources of volcaniclastic particles, such as a shift from deep- to shallow-water volcanism. In order to examine this aspect, we have applied fractal analysis to sideromelane grains to check for morphometric changes that might indicate such shifts. This analysis is based on the suggestion by Honnorez and Kirst (1975) that sideromelane shards produced by deep-water volcanism should exhibit simpler grain boundaries than those particles produced by more explosive activity closer to the surface.

Sideromelane shards from Unit $\mathrm{V}$ exhibit a wide range in morphology from simple blocky grains to well-vesiculated structures. Fractal analysis is able to distinguish these two end-members with little difficulty. Blocky grains are characterized by a single linear segment on Richardson plots and have low values of $D$ (Fig. 13). In contrast, vesicular clasts have at least two linear segments (Fig. 14). The first linear segment, consisting of the smaller step length, corresponds to a textural fractal $(D 1)$, and the second segment, with larger step lengths, is a reflection of the structural fractal $(D 2)$. In the case of these particles, the latter is controlled by the size and abundance of vesicles that intersect the particle boundary (Fig. 14). Two fractal dimensions may be calculated for such vesicular particles, with the structural fractal typically showing the larger value.

Fractal analysis was carried out on a suite of samples from selected depths from the base to the top of Unit V (Fig. 15). In each sample, analysis was carried out only on the largest sideromelane grains (200-500 $\mu \mathrm{m}$ diameter). Virtually all particles exhibited multifractal behavior, and consequently two fractal dimensions (D1 and D2) were calculated from linear regressions of the data. Figure 15 shows an increase in the value of $D l$ from the base to the top of Unit $\mathrm{V}$. This trend indicates an increase in the complexity of particle morphology during the deposition of Unit V. This increase in complexity can be attributed to more vesicular sideromelane becoming abundant in the younger sediments of Unit V.

Median values of the $D 2$ fractal dimension show a very slight increase in Unit V from the base to the top, although the change is unlikely to be statistically significant. However, there is a distinct increase in the range of $D 2$ values found at any particular depth when moving from the base to the top of Unit V (Fig. 15). The basal section is characterized by a relatively narrow range (1.08-1.25), whereas the upper deposits have a larger range $(1.08-1.37)$. D2 values above 1.25 are produced by highly irregular particles with high degrees of vesicularity (see Fig. 14).

\section{DISCUSSION \\ Production of Volcaniclastic Debris}

Schmincke and von Rad (1979) identified three major processes for the production of mafic volcaniclastic material in an oceanic island environment: (1) generation of vesicular and blocky sideromelane shards by the interaction of water and magma under submarine conditions; (2) fragmentation of lava flows as they enter the sea, producing large quantities of tachylite and crystalline rock fragments; and (3) erosion of pre-existing subaerial volcanic and plutonic formations, with subsequent river transport to the sea. Sediment gravity flow deposits from Unit V contain significant proportions of each of these types of particles, thereby indicating the important role of submarine volcanism, the entrance of lava flows into the sea, and the erosion of a subaerial edifice during deposition of this unit.

The ubiquitous presence of tachylite and well-rounded crystalline rock fragments argues for the existence of a subaerial edifice at this time (Fig. 10). We suggest that the gradual increase in tachylite abundance upsection in Unit V is caused by the more frequent generation of this material by lava flows entering the sea as the subaerial edifice grew in size and more vents were located on land than in a shallowwater environment. However, the persistence of sideromelane shards throughout the unit indicates that submarine volcanism continued to contribute material during this period. In addition, the fractal analysis results indicate that the morphology of sideromelane particles becomes more complex (i.e., vesicular) during the deposition of Unit V. This provides additional support for the shifting of eruptive vents to progressively more shallow-water and subaerial locations.

A characteristic feature of the Unit V flow deposits is their strongly mixed nature. Unlike volcaniclastic deposits from Site 397 south of Gran Canaria, the Site 953 deposits exhibit a broad range in lithology as a result of the mixing of components from the three major clast-generating processes (Fig. 9). We suggest that the mixed nature of the deposits is the result of the clastic material staging in shallow water and on the flanks of the volcano (Fig. 16). Some deposits may be directly related to eruptive events, but we believe that the majority represent transport of material from an area where particles from multiple sources were being mixed together. We envision that during this time eruptive activity was relatively high both in the subaerial and submarine environments, producing a rapid flux of volcaniclastic material to the marine environment.

This situation contrasts greatly with the processes taking place before the deposition of Unit V, when Unit VI was accumulating. At this time, Site 953 was receiving large amounts of volcaniclastics in the form of hyaloclastite debris flows and breccias with pillow fragments (Shipboard Scientific Party, 1995). Virtually no interbedded pelagic sediment was accumulating, attesting to the very high sedimentation rate. The transition from Unit VI to V could be interpreted in two ways. One hypothesis is that the reduction in the bed thickness from VI to V was the result of a decrease in the total volcanic production rate in the source areas of the flow deposits. An alternative hypothesis is that the rate of volcanic production was relatively constant, but that the production of volcaniclastic material was reduced in Unit V relative to Unit VI, because more of the vents were located in the subaerial environment. Thus, less clastic material was generated.

\section{Initiation of Sediment Gravity Flows}

Sediment gravity flows can be initiated in areas of active volcanism by (1) rapid influx of material to the marine environment associ- 
A.

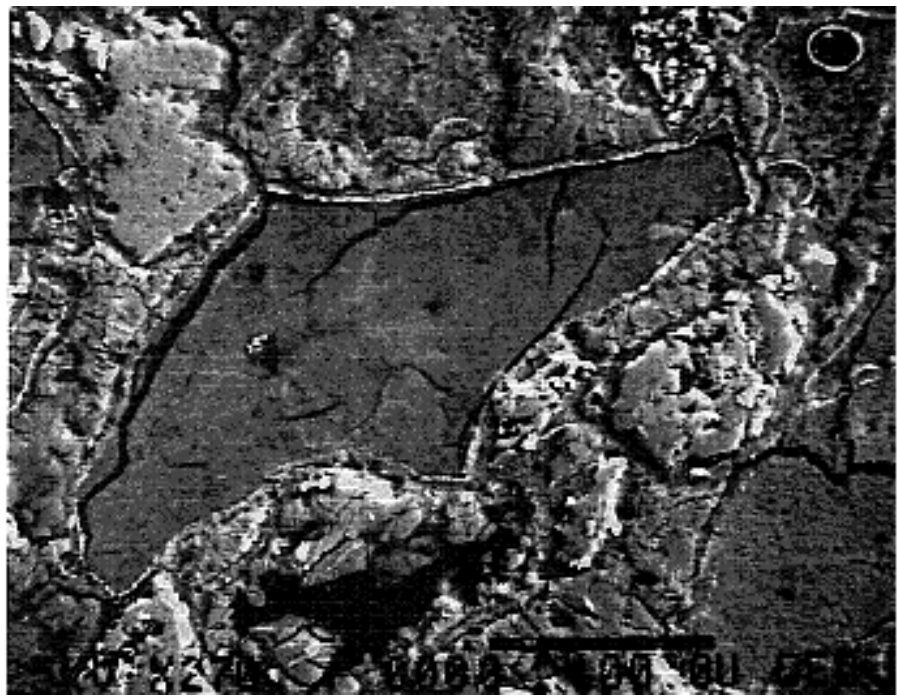

Figure 13. A. SEM digital image of blocky sideromelane shard from Unit V, Site 953 (157-953C-72R$5,63-65 \mathrm{~cm}$ ); scale bar $=100 \mu \mathrm{m}$. The "bright" rim of the shard consists of fine-grained Ti-rich Fe-Ti oxides. B. Binary image of shard shown in A. C. Richardson plot of log perimeter vs. log ruler, based on fractal analysis of binary image boundary. $D$ is the fractal dimension, based on the slope of the linear regression.

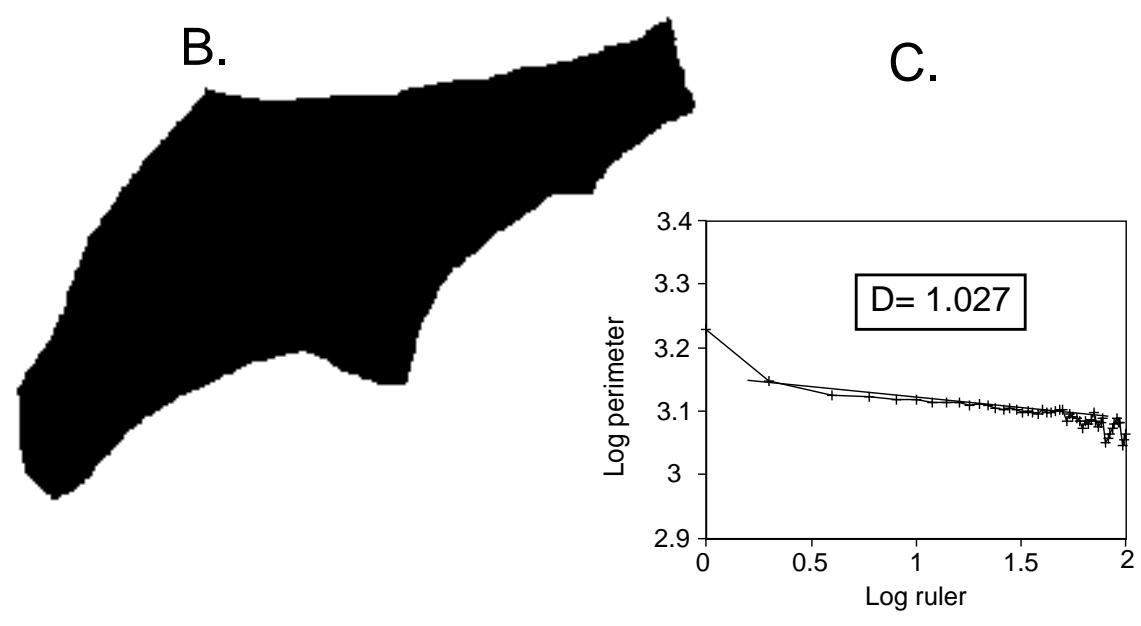

ated with a specific volcanic event, such as entry of lava flows, pyroclastic flows, or lahars into the ocean; (2) failure of an oversteepened accumulation of clastic material in shallow water; (3) slumping of clastic material as a result of seismic activity; or (4) storm activity. A distinctive feature of the sediment gravity flow deposits in Unit V is their relatively uniform thickness (Fig. 2) and frequency (Fig. 5). Many turbidite sequences in the marine environment exhibit these same features (Pickering et al., 1989). These characteristics have been attributed to a steady source of clastic sediment, coupled with a periodic triggering mechanism such as storms or failure of oversteepened slopes.

The highly mixed nature of the sediment gravity flow deposits in Unit V suggests that alternative (1) is not the controlling factor in the generation of the deposits. If it were, the deposits would be more juvenile rich. Influx of material is likely to be taking place, but there is little evidence for synchronous production of flow events. We believe that it is more likely that periodic failure of unconsolidated volcaniclastic sediment in shallow water was the mechanism of flow generation. Our model is that clastic material was being supplied at a steady rate to the shallow submarine environment by influx of epiclasts from fluvial action, entrance of lava flows into the sea with generation of tachylite, and submarine volcanism, producing sideromelane shards. This shallow clastic apron (Fig. 16) was accumulating at a rate sufficient for periodic slumping of its distal margin into deeper water to take place. Some of the flows were high-particle con- centration flows that moved as debris flows. More dilute flows were most likely generated by flow transformation processes (e.g., Fisher, 1983; Hampton, 1972). The slumping process may have been aided by the frequent seismic activity that was likely to accompany ongoing volcanism.

\section{Sources of Volcaniclastic Material}

Site 953 lies within a basin that is surrounded to the southwest, south, and southeast by the islands of Tenerife, Gran Canaria, Fuerteventura, and Lanzarote. Each of these islands represents potential sources of volcaniclastic material. A key to the understanding of the source of volcanic material in Unit V is the correlation of felsic and intermediate volcaniclastic material in other units of Site 953 with subaerial volcanic formations on Gran Canaria (Shipboard Scientific Party, 1995). For example, based on geochemical and mineralogical criteria, a specific subaerial pyroclastic flow deposit, P1 (Schmincke, 1994; Freundt and Schmincke, 1995), has been correlated with a deposit in Core 157-953C-70R. Furthermore, the tempo and composition of the major volcanic activity and formations on Gran Canaria are reflected in the majority of volcaniclastic deposits at Site 953. Given this observation, it is reasonable to assume that the likely source of mafic volcaniclastics deposited just before the onset of felsic volcanism were also derived from Gran Canaria and represent part of the shield-building stage. 
A.

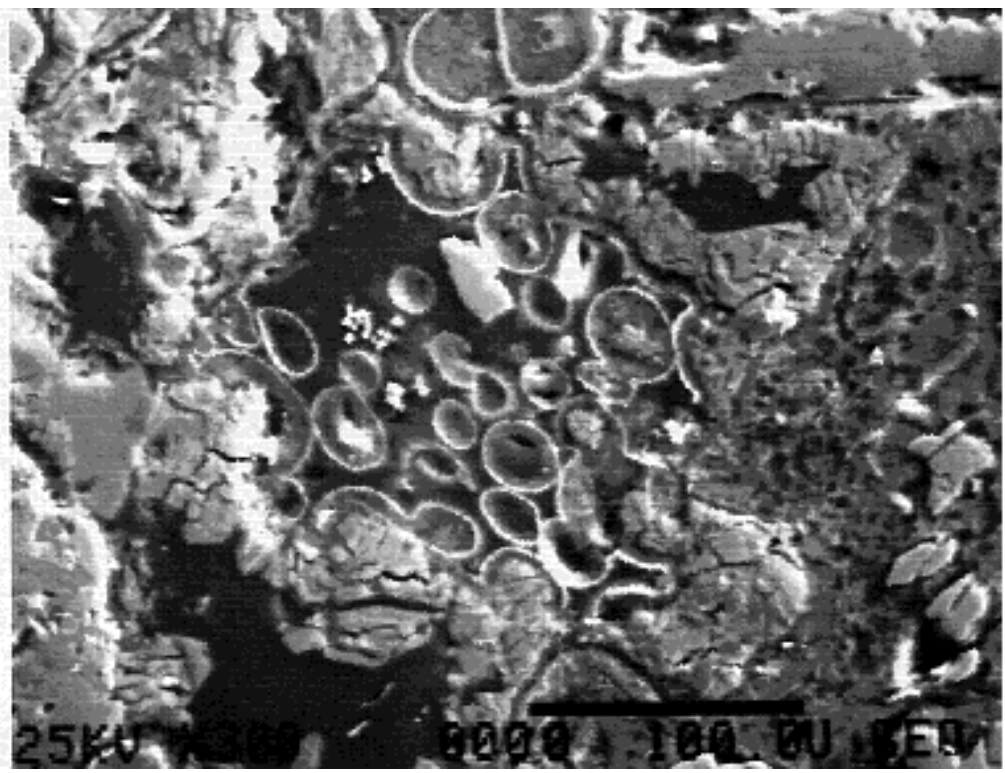

B.

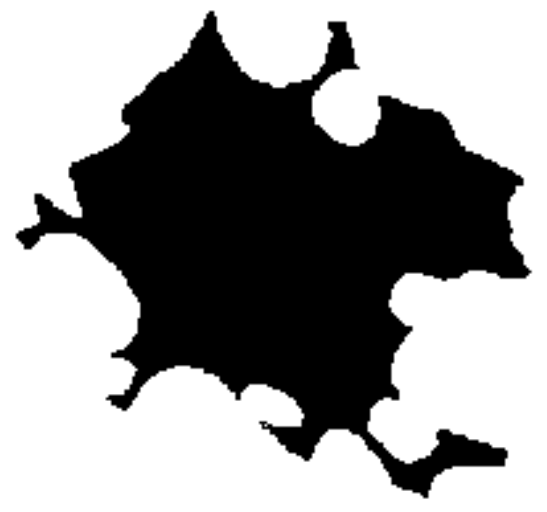

C.

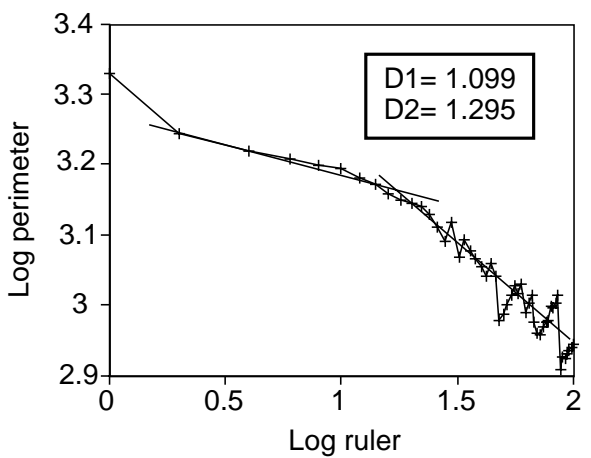

Figure 14. A. SEM digital image of vesicular sideromelane shard from Unit V, Site 953 (157-953C72R-5, 63-65 cm); scale bar $=100 \mu \mathrm{m}$. B. Binary image of shard shown in A. C. Richardson plot of $\log$ perimeter vs. $\log$ ruler, based on fractal analysis of binary image boundary. $D 1$ and $D 2$ are the fractal dimensions, based on the slopes of the linear regressions of the shallow and steep segments, respectively.
Unit $\mathrm{V}$ is inferred to span the time interval from $\sim 14.1$ to $14.5 \mathrm{Ma}$, although age constraints are difficult because of the paucity of interbedded pelagic sediments. Nevertheless, the younger age boundary is well constrained by the occurrence of the radiometrically dated pyroclastic flow material correlated with unit P1 on Gran Canaria. On Gran Canaria, the oldest exposed rocks are a series of basaltic flows underlying flow unit P1 and reaching up to $1000 \mathrm{~m}$ above sea level (Schmincke, 1994). These flows consist mostly of alkalic transitional to tholeiitic basalts that are rich in $\mathrm{Ti}$ and $\mathrm{Fe}$, and have $\mathrm{Nb}>40 \mathrm{ppm}$ and $\mathrm{Zr}>300 \mathrm{ppm}$. Perhaps most important, Schmincke (1994) has recognized evidence for extensive erosion and slumping of the eastern part of the shield volcano before the beginning of felsic volcanism at $\sim 14 \mathrm{Ma}$. The fanglomerates and coarse-grained epiclastic sediments associated with this period may thus be correlative to the volcaniclastic material found in Unit V at Site 953.

\section{CONCLUSIONS}

Site 953 of Leg 157 provides a unique opportunity to reconstruct the volcanic evolution of Gran Canaria in the Canary Island archipelago. Since the middle Miocene, submarine and subaerial volcanism has contributed clastic sediment to the island's margins and con- structed a major volcaniclastic apron. Following deposition of thick hyaloclastite debris flows at $\sim 14.5 \mathrm{Ma}$, sedimentation at Site 953 shifted to the emplacement of numerous thin- to medium-bedded mafic volcaniclastic turbidites (Unit V). This style of deposition persisted until the initiation of felsic explosive volcanism correlative to the subaerial Mogán Formation on Gran Canaria.

The mafic turbidites consist of mixtures of altered sideromelane, tachylite, small clasts of microcrystalline basalt, and crystals of clinopyroxene, feldspar, and Fe-Ti oxides. Biogenic components, such as foraminifer fragments, range as much as $30 \%$. Fractal and modal analyses of the turbidite deposits indicate that during deposition of Unit V, the complexity of sideromelane particle morphology and the abundance of tachylite both increased from the base to the top of the unit.

The strongly mixed lithologies of the turbidites and the occurrence of common rounded microcrystalline basalt fragments suggest that many of the layers were formed by the slumping of volcaniclastic material that had accumulated in shallow water following accumulation of material from erosion of subaerial products, entrance of lava flows into the sea, and shallow submarine eruptions. A median frequency of one flow event every $2000 \mathrm{yr}$ has been determined by the thickness and accumulation rate of interbedded pelagic sediment in Unit $\mathrm{V}$. 


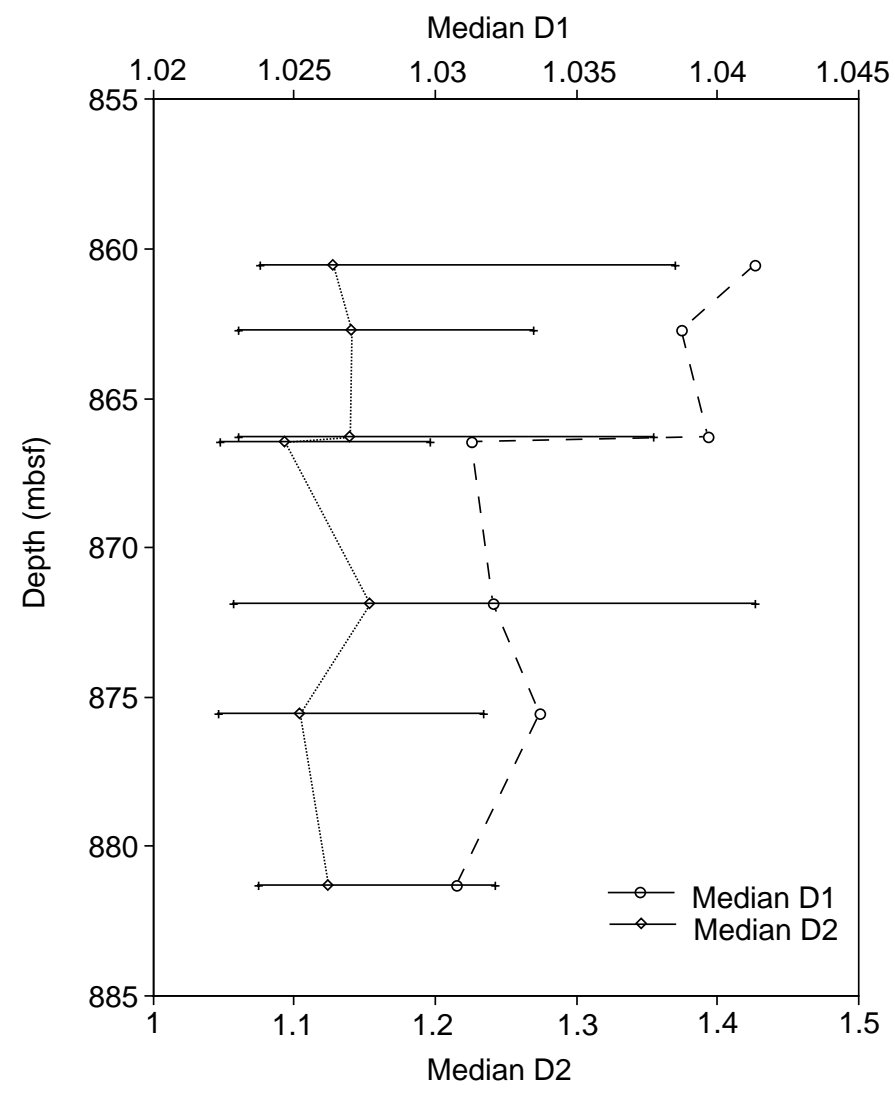

Figure 15. Variation in median fractal dimensions (D1 and $D 2)$ of sideromelane shards as a function of sub-bottom depth in Unit V, Site 953. Horizontal lines on the $D 2$ data points indicate the range of values at that depth.

\section{REFERENCES}

Bayliss, P., 1986. Quantitative analysis of sedimentary minerals by powder X-ray diffraction. Powd. Diffr., 1:37-39.

Carey, S., and Sigurdsson, H., 1978. Deep-sea evidence for distribution of tephra from the mixed magma eruption of the Soufiere of St. Vincent, 1902: ash turbidites and air fall. Geology, 6:271-274.

Danforth, W., 1986. Petrology and structural relations of the western Scituate granite [Master's thesis]. Univ. of Rhode Island, Kingston.

Fisher, R. V., 1983. Flow transformation in sediment gravity flows. Geology, 11:273-274.

Fisher, R.V., and Schmincke, H.-U., 1984. Pyroclastic Rocks: New York (Springer-Verlag).

Freundt, A., and Schmincke, H.-U., 1995. Petrogenesis of rhyolite-trachytebasalt composite ignimbrite P1, Gran Canaria, Canary Islands. J. Geophys. Res., 100:455-474.

Hamidzada, N., 1988. Petrology, geochemistry and structure of the northeastern part of the Scituate pluton, Rhode Island [Master's thesis]. Univ. of Rhode Island, Kingston.
Hampton, M.A., 1972. The role of subaqueous debris flow in generating turbidity currents. J. Sediment. Petrol., 42:775-793.

Heiken, G., and Wohletz, K., 1991. Fragmentation processes in explosive volcanic eruptions. In Fisher, R.V. and Smith, G.A. (Eds.), Sedimentation in Volcanic Settings. Spec. Publ.—Soc. Econ. Palentol. Mineral., 45:1926.

Honnorez, J., and Kirst, P., 1975. Submarine basaltic volcanism: morphometric parameters for discriminating hyaloclastites from hyalotuffs. Bull. Volcanol., 39:1-25.

Kaye, B.H., 1986. Image analysis procedures for characterizing the fractal dimension of fine particles. Proc. Particle Technol. Conf., Nurenberg, Germany.

Krinsley, D., 1985. Environmental interpretation of quartz grain surface textures. In Zuffa, G.G. (Ed.), Provenance of Arenites: Dordrecht (D. Reidel), 213-229.

Krinsley, D., and Doornkamp, J., 1973. Atlas of Quartz Sand Surface Textures: Cambridge (Cambridge Univ. Press).

Mandelbrot, B.B., 1967. How long is the coast of Britain? Statistical selfsimilarity and fractal dimension. Science, 156:636-638.

Margolis, S.V., and Kennett, J.P., 1970. Antarctic glaciation during the Tertiary recorded in sub-Antarctic deep-sea cores. Science, 170:1085-1087.

Orford, J.D., and Whalley, W.B., 1983. The use of fractal dimension to quantify the morphology of irregular-shaped particles. Sedimentology, 30:644-668.

Pickering, K.T., Hiscott, R., and Hein, F.J., 1989. Deep-marine Environments: Clastic Sedimentation and Tectonics: London (Unwin Hyman).

Russ, J.C., 1992. The Image Processing Handbook: Ann Arbor (CRC Press).

Schmincke, H.-U., 1982. Volcanic and chemical evolution of the Canary Islands. In von Rad, U., Hinz, K., Sarnthein, M., and Seibold, E. (Eds.), Geology of the Northwest African Continental Margin: Berlin (Springer), 273-306.

1993. Geological Field Guide: Gran Canaria (6th ed.): Kiel, Germany (Pluto Press).

Schmincke, H.-U., and von Rad, U., 1979. Neogene evolution of Canary Island volcanism inferred from ash layers and volcaniclastic sandstones of DSDP Site 397 (Leg 47A). In von Rad, U., Ryan, W.B.F., et al., Init. Repts. DSDP, 47 (Pt. 1): Washington (U.S. Govt. Printing Office), 703725.

Schmincke, H.-U., Weaver, P., and Firth, J.V., 1994. Leg 157 Scientific Prospectus. Ocean Drilling Program.

Schmincke, H.-U., Weaver, P.P.E., Firth, J.V., et al., 1995. Proc. ODP, Init. Repts., 157: College Station, TX (Ocean Drilling Program).

Sheridan, M., and Marshall, J.R., 1983a. Interpretation of pyroclastic surface features using SEM images. J. Volcanol. Geotherm. Res., 16:153-159. , 1983b. Scanning electron microscopic examination of pyroclastic materials: basic considerations. Scanning Electron Microsc., 1:113-118.

Shipboard Scientific Party, 1995. Site 953. In Schmincke, H.-U., Weaver, P.P.E., Firth, J.V., et al., Proc. ODP, Init. Repts., 157: College Station, TX (Ocean Drilling Program), 317-394.

Viereck, L.G., Griffin, B.J., Schmincke, H.-U., and Pritchard, R.G., 1982. Volcaniclastic rocks of the Reydarfjordur Drill Hole, eastern Iceland. 2. Alteration. J. Geophys. Res., 87:6459-6476.

Date of initial receipt: 1 July 1996

Date of acceptance: 23 April 1997

Ms 157SR-119 


\section{Unit VI}

Sealevel

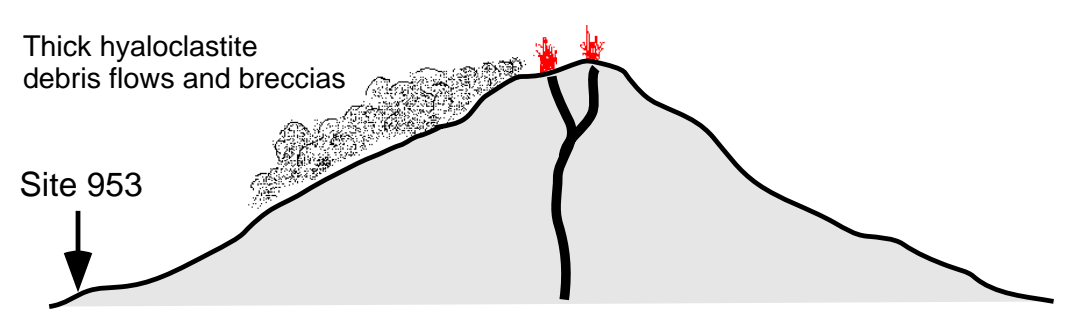

High magma production rate

Shield building stage

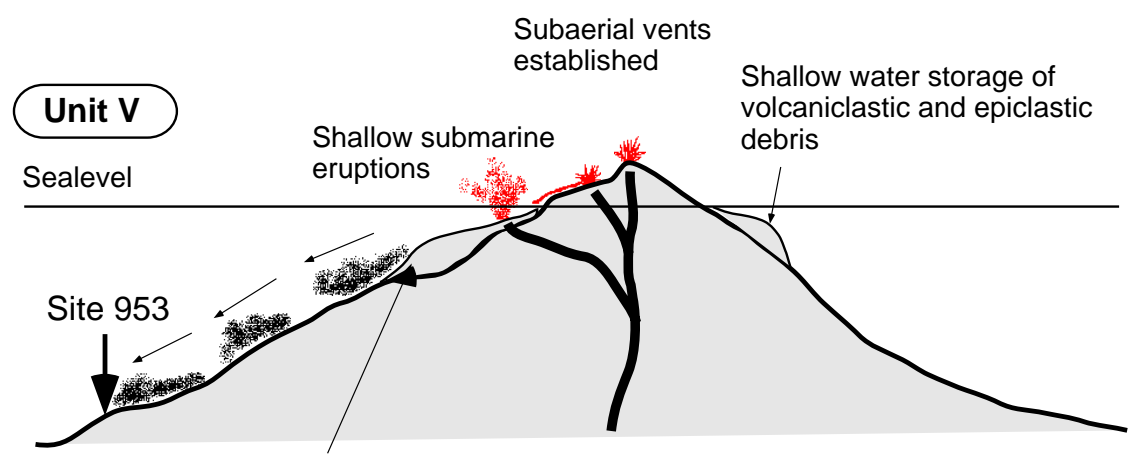

Frequent production of small scale turbidites
Figure 16. Model for the volcaniclastic sedimentation processes inferred from the sediments in Units $\mathrm{V}$ and VI, Site 953. 


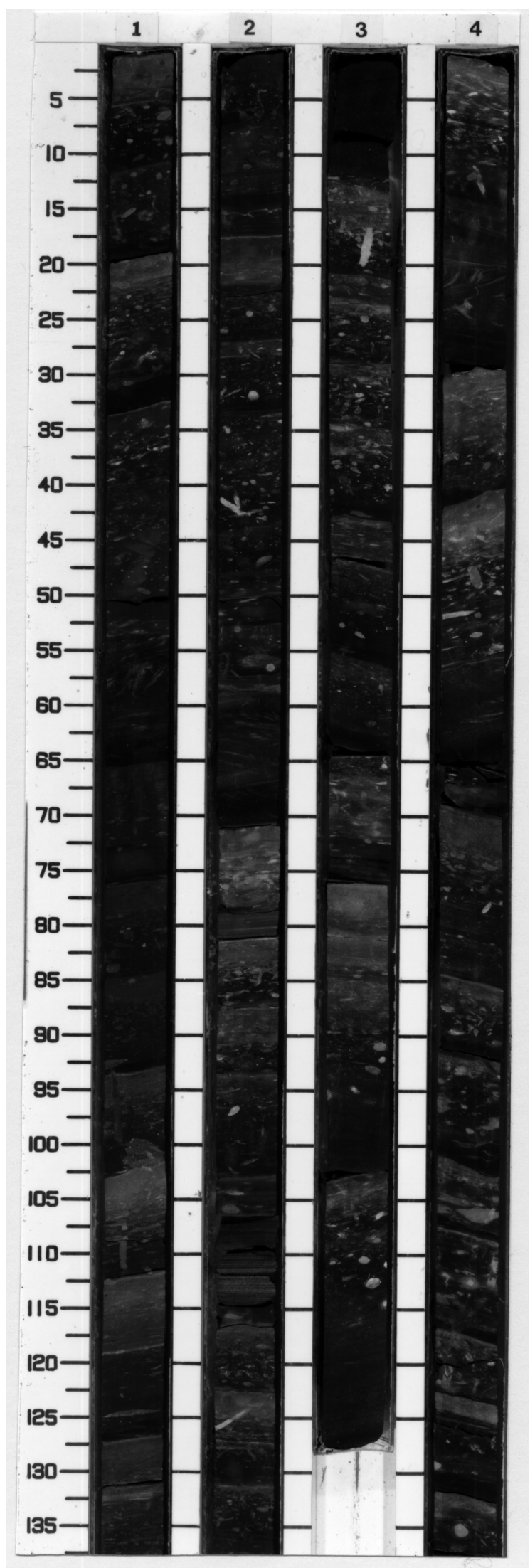

Plate 1. Shipboard core photograph of volcaniclastic turbidites in Unit V, Site 953 (Sections 157-953C-73R-1 through 73R-4). Note the abundance of normally graded beds with sharp bases and bioturbated tops. 


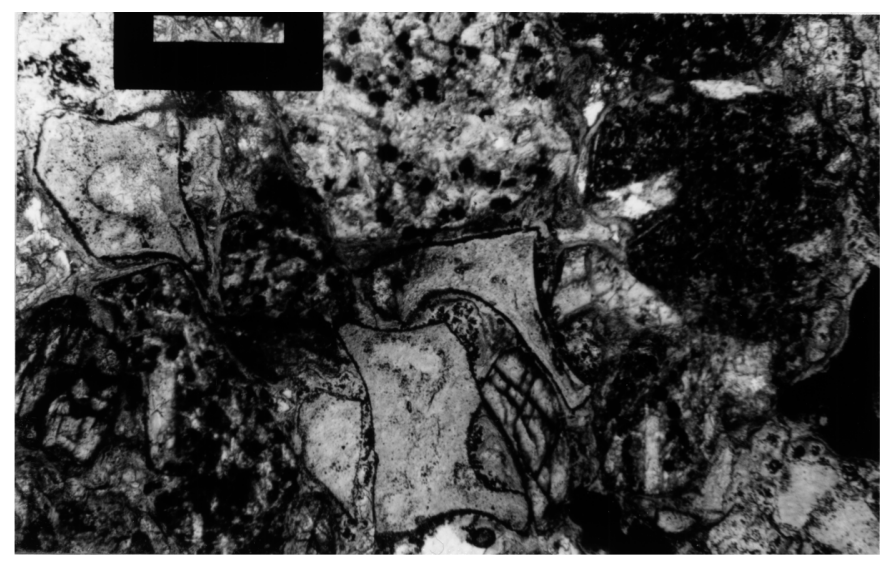

1
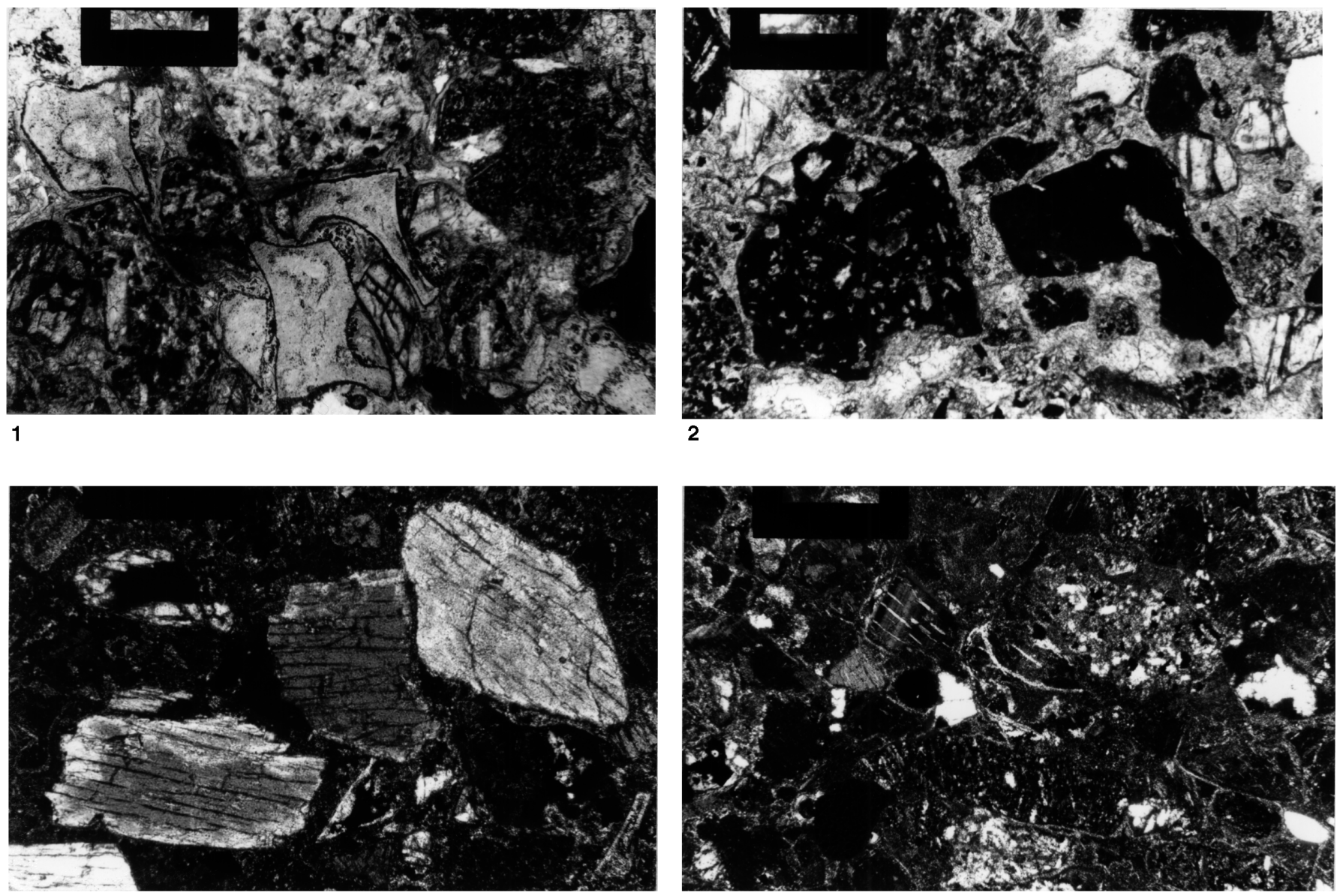

3

4

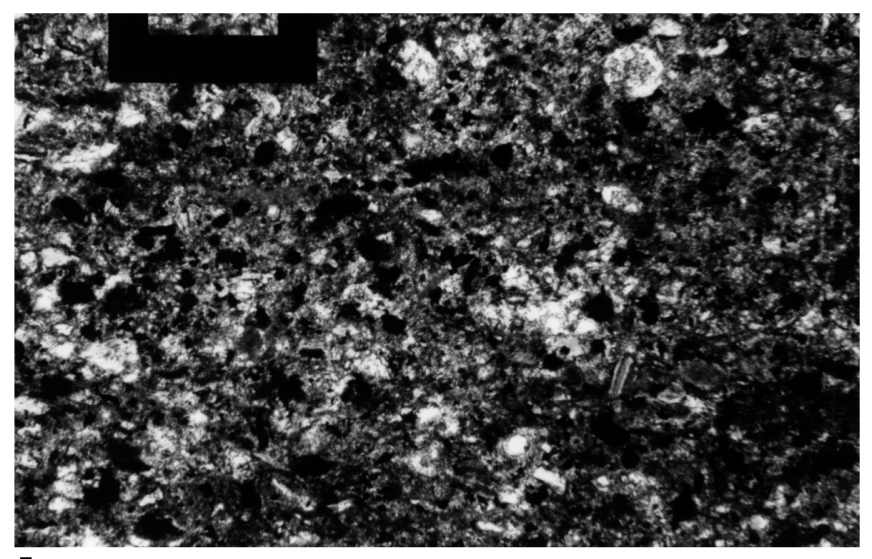

5

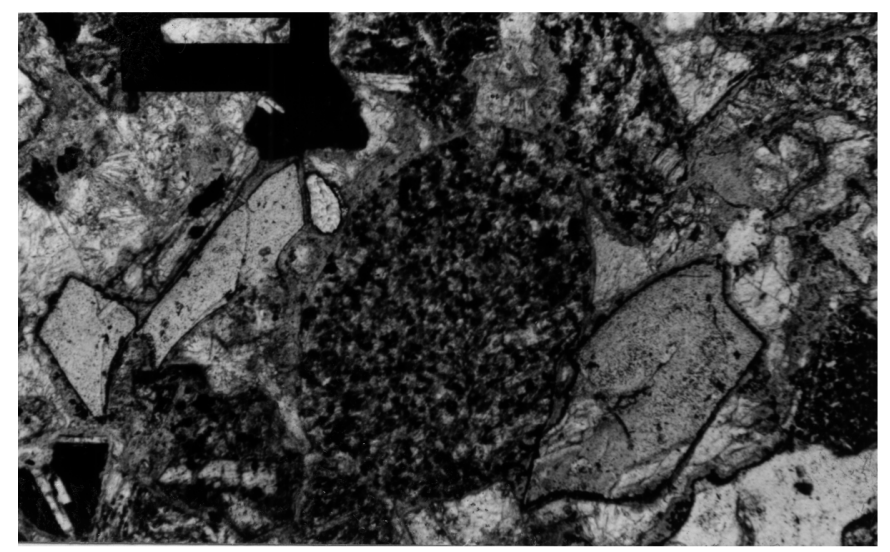

6

Plate 2. Photomicrographs of the major lithologic components in volcaniclastic turbidite deposits from Unit V, Site 953 . Scale bars are $200 \mu \mathrm{m}$ long. 1. Sample 157-953C-72R-5, 83-85 cm; altered cuspate shards of sideromelane. 2. Sample 157-953C-72R-1, 11-13 cm; two large grains of tachylite. Grain on the left contains microlites of feldspar and clinopyroxene. 3. Sample 157-953C-72R-1, 11-13 cm; three large grains of subhedral clinopyroxene (crossed nichols). 4. Sample 157-953C-72R-2, 4-6 cm; subhedral grain of plagioclase (pl) in a matrix of altered sideromelane, basalt clasts, tachylite, and minor amount of biogenic components 5. Sample 157-953C-75R-1, 19-21 cm; small subhedral to anhedral grain of Fe-Ti oxides in a matrix of altered sideromelane, clinopyroxene, tachylite, and minor amount of biogenic components. 6. Sample 157-953C-72R-2, 4-6 cm; rounded clast of microcrystalline basalt consisting of microlites of plagioclase, clinopyroxene, and Fe-Ti oxides. 

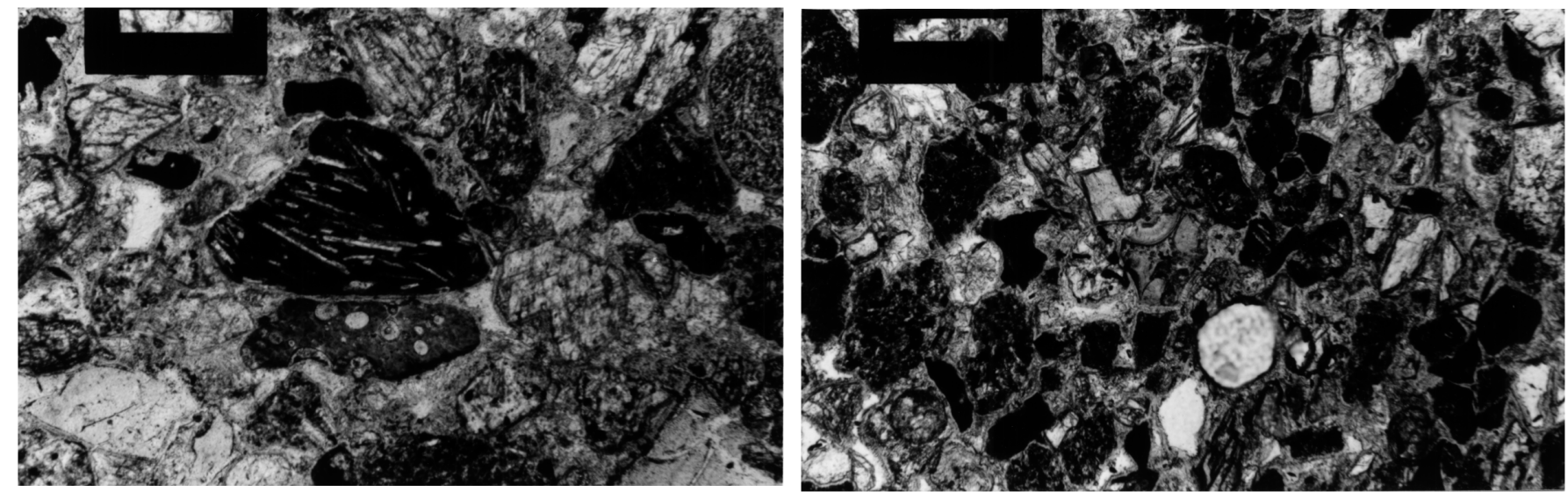

1

2
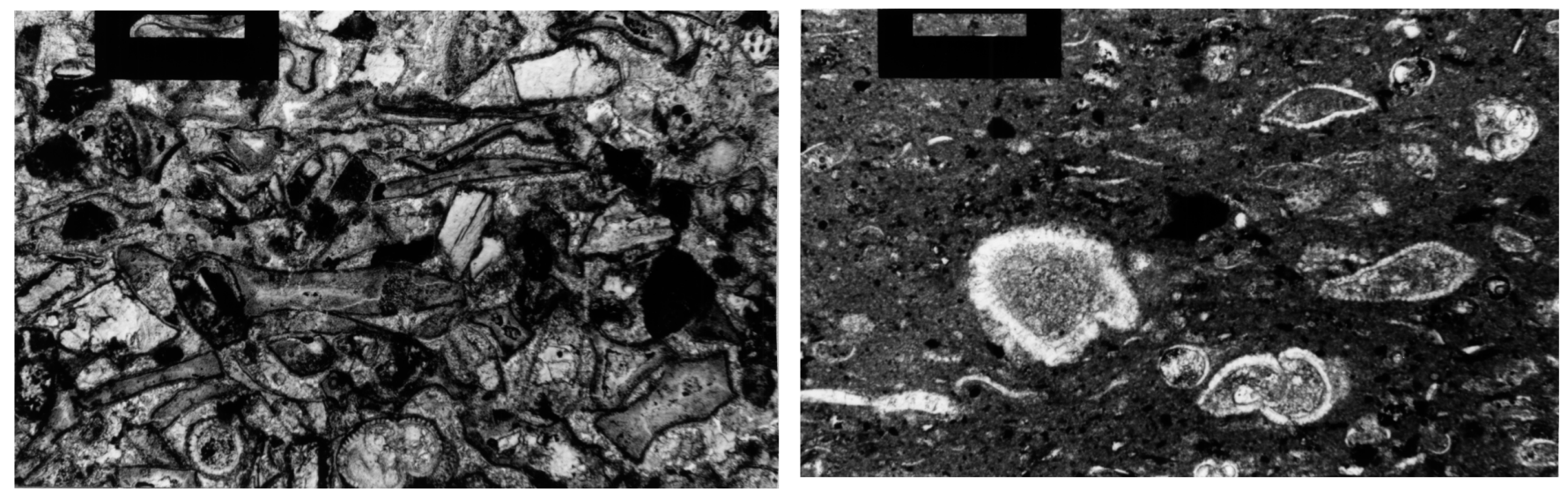

3

4

Plate 3. Photomicrographs of lithologic variations in sediments from Unit V, Site 953. Scale bars are $200 \mu \mathrm{m}$ long. 1. Sample 157-953C-72R-2, 4-6 cm; epiclastic sandstone consisting of rounded microcrystalline basalt fragments, altered sideromelane grains, subhedral clinopyroxene crystals, tachylite, and fine-grained matrix. 2. Sample 157-953C-71R-5, 8-10 cm; fine-grained epiclastic sandstone with abundant tachylite grains, altered sideromelane, subhedral clinopyroxene, rounded microcrystalline basalt fragments, and fine-grained matrix. 3. Sample 157-953C-73R-2, 68-70 cm; fine-grained hyaloclastite with minor amounts of biogenic fragments, predominantly foraminifers, and fine-grained matrix. 4. Sample 157-953C-73R-3, 75-77 cm; mixed sediment with common foraminifer fragments and small tachylite grains from pelagic interbeds in Unit V. 